OECD Corporate Governance Working Papers No. 20

Corporate Governance of Financial Groups

Takahiro Yasui

https://dx.doi.org/10.1787/5jlv1m6zq3nx-en 


\section{OECD CORPORATE GOVERNANCE WORKING PAPERS}

OECD Corporate Governance Working Papers provide timely analysis and information on national and international corporate governance issues and developments, including state ownership and privatisation policies. The working paper series is designed to make select studies by the OECD Corporate Governance Committee, OECD staff members and outside consultants available to a broad audience.

The papers are generally available only in their original language, English or French, with a summary in the other if available.

OECD Working Papers should not be reported as representing the official views of the OECD or of its member countries. The opinions expressed and arguments employed are those of the authors.

Working Papers describe preliminary results or research in progress by the author(s) and are published to stimulate discussion on a broad range of issues on which the OECD works. Comments on Working Papers are welcomed, and may be sent to corporate.affairs@oecd.org or Directorate for Financial and Enterprise Affairs, Corporate Affairs Division, OECD, 2 rue AndréPascal, 75775 Paris Cedex 16, France.

This document and any map included herein are without prejudice to the status of or sovereignty over any territory, to the delimitation of international frontiers and boundaries and to the name of any territory, city or area.

\section{OECD CORPORATE GOVERNANCE WORKING PAPERS}

are published on www.oecd.org/daf/corporateaffairs/wp

(C) OECD 2016

Applications for permission to reproduce or translate all or part of this material should be made to: OECD Publishing, rights@oecd.org or by fax 33145249930. 


\title{
Corporate Governance of Financial Groups
}

\author{
by \\ Takahiro Yasui*
}

\begin{abstract}
Companies today, in particular banks, insurance companies and other financial institutions, increasingly operate their businesses in a group structure. These financial groups have a growing presence in markets worldwide and the economy as a whole. To do business effectively and efficiently in group structures, corporate groups should be managed in a holistic and integrated manner, in much the same way as an enterprise. Good governance of corporate groups should not therefore be very different from that of a corporation with many departments and branches. Nonetheless, the idiosyncratic risks that group structures bring about may require particular attention be paid to the governance of corporate groups. Such risks include the complexity of group structures and responsibilities among member companies in a multi-layered ownership structure across borders. The legal status of subsidiary companies, which is different from departments or branches of a corporation, should be respected. The governance of corporate groups needs to address inherent issues such as the dilemma of subsidiary boards' loyalty to the interests of the subsidiary versus the broader interests of the group, and the risks associated with related party transactions. In the case of financial groups, particular consideration should be given to the interests of depositors and insurance policyholders of each financial subsidiary. Financial regulation increasingly establishes requirements for the governance responsibilities of the boards of financial subsidiaries, while emphasising the overall responsibility of the ultimate parents of financial groups.
\end{abstract}

Authorised for release by Pierre Poret, Deputy Director, OECD Directorate for Financial and Enterprise Affairs

JEL Codes: G30, G32, G34, G38

Key words: corporate governance, corporate groups, financial groups, financial regulation, group structure, parent board, subsidiary board, fiduciary duty

This paper was prepared by Takahiro Yasui, Head of Special Projects and Outreach Unit, Directorate for Financial and Enterprise Affairs, OECD. It was originally presented at the meeting of the Indonesia-OECD Policy Dialogue on Corporate Governance held in Jakarta on 2 December 2015. The author is grateful for valuable inputs from the OECD colleagues, particularly Winfrid Blaschke, Daniel Blume, Serdar Celik, Matthew Cooper, Fianna Jurdant and Stephen Lumpkin, as well as Mr. Nursantyo of the Indonesian Financial Services Agency (OJK). The views expressed in this paper are those of the author and do not represent those of the OECD or its member countries. 

TABLE OF CONTENTS

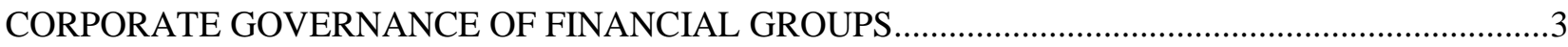

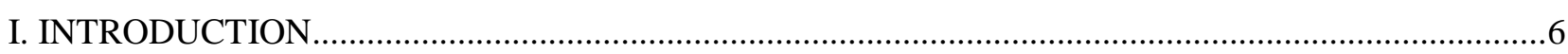

II. LEGAL FRAMEWORK FOR CORPORATE GROUPS …..........................................................

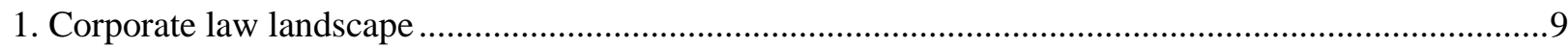

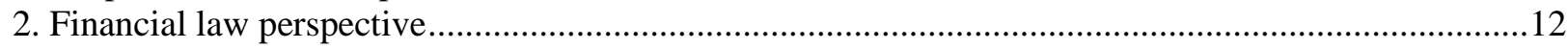

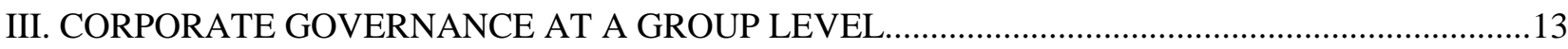

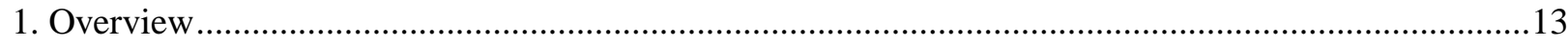

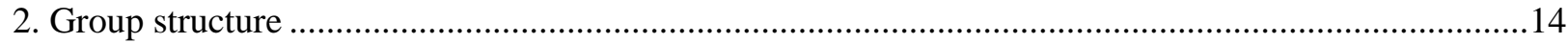

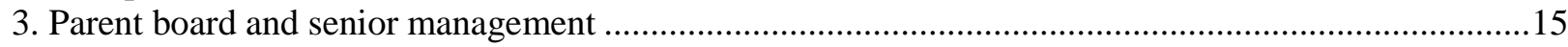

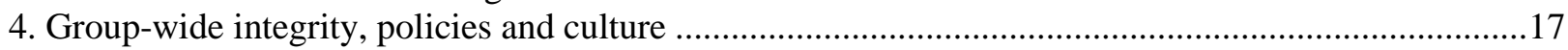

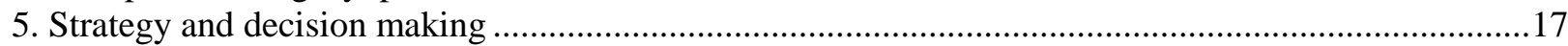

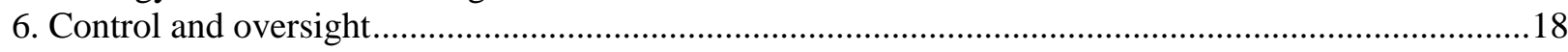

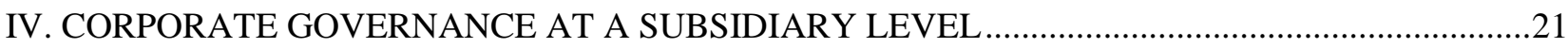

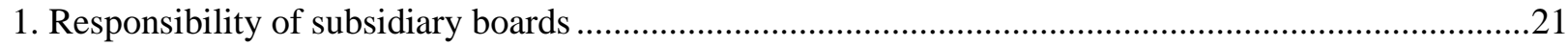

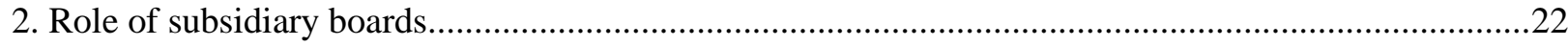

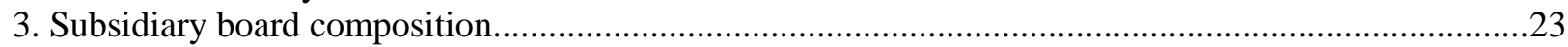

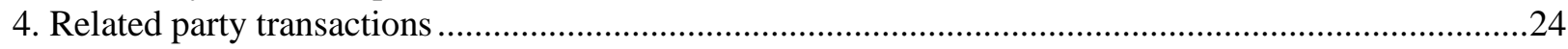

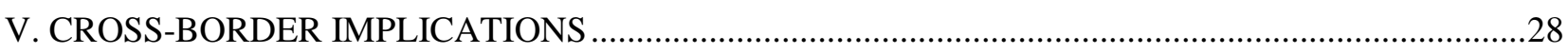

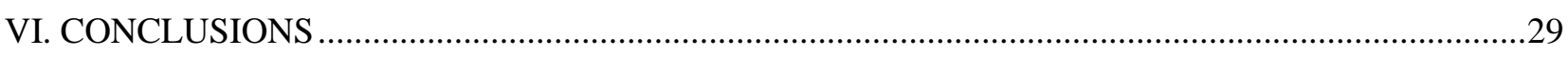

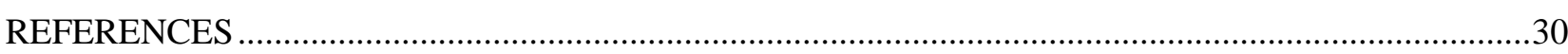

APPENDIX A CORPORATE GOVERNANCE PRINCIPLES FOR BANKS, BASEL COMMITTEE

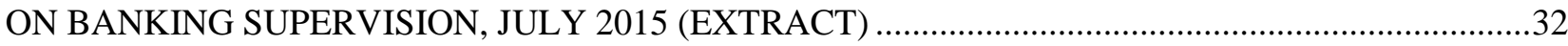

APPENDIX $B$ PRINCIPLES FOR THE SUPERVISION OF FINANCIAL CONGLOMERATES,

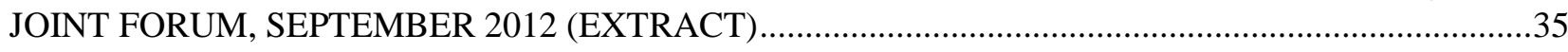

APPENDIX C OECD GUIDELINES ON INSURER GOVERNANCE, 2011 (EXTRACT).....................42

APPENDIX D INSURANCE CORE PRINCIPLES, INTERNATIONAL ASSOCIATION OF INSURANCE SUPERVISORS, UPDATED NOVEMBER 2015 (EXTRACT) .......................................43 


\section{INTRODUCTION}

Today it is common to see large companies form groups to conduct their activities, especially on a cross-sector or cross-border basis. Companies create subsidiaries for various reasons: for separating the risk of a new business, for setting a different remuneration system for certain employees, and popularly for tax purposes. Corporate groups may also be formed through capital transactions between companies, including mergers and acquisitions. In the case of large, internationally active corporate groups, it is not rare to see a multitude of member companies within them. Corporate group structures have become increasingly more complex worldwide.

The same phenomenon can be observed in the financial sector. Most if not all of large-scale banks, insurance companies and other financial services providers have established a corporate group often with a number of subsidiaries domestically and internationally. Financial regulation itself may give rise to group formation by requiring a separately capitalised legal entity for certain financial businesses, such as banking and insurance. In many jurisdictions, a bank and an insurance company must be segregated into different entities, and by doing so concurrently, a group structure would need to be established. The recent global financial crisis highlighted the risk contagion from risky investment banking activities to retail deposit taking operations. In response, for example, the recent regulatory reforms in the United Kingdom requires "ring-fencing" a deposit-taking institution from other parts of group businesses, an important influence on the structures of financial groups in the United Kingdom.

\section{Benefits and risks of group structure}

Corporate groups, including financial groups, are formed based on business judgements, supported by a variety of reasons, all within particular contexts. In some cases, a separate legal entity may be required by law or regulation to start a certain business in the jurisdiction. In other cases, tax advantages may be the main driver for setting up a subsidiary. Economically speaking, forming a group may potentially benefit from economies of scale and scope as well as risk diversification (Lumpkin 2011). In the case of financial groups, economies of scale may be present when member companies share common administrative functions. Geographical diversification may lead to lower costs and a more efficient allocation of capital. There may be economies of scope found in product cross-selling. For example, a bank in the group sells to its customers an insurance product of an insurance company in the same group. The diversification of the businesses may also contribute to lower failure risk of the group as a whole. Yet the magnitude of such benefits depends considerably on the nature, conditions and environment of the businesses run by a particular group.

Also, corporate group structures can give rise to idiosyncratic risks, which are largely derived from the diversification and inter-connectedness of the businesses in a group. The first type of such risks is the risk of contagion. The diversified businesses run by various members are naturally difficult to manage, and troubles at the small corner of the group may be overlooked. In a group structure, these troubles could bring about a big problem to the group as a whole through a capital nexus, intra-transactions or reputation. As seen in the recent global financial crisis, the risk of contagion may pose a serious threat to financial groups in particular as some types of financial businesses depend considerably on public confidence.

The second category involves those risks associated with intra-group transactions. The transactions between member companies could be the source of benefits for group organisation, particularly with reduced transaction costs. But they may also be used to transfer assets, profits or risks arbitrarily among the constituent companies or purposefully among them, as in the case of tax arbitrage. Where regulated 
financial institutions are involved in such transactions, there is the risk that the stability of the institutions could be placed in jeopardy.

The third category includes the risks of concentration, conflicts of interest and double gearing, which may be associated with the difficulty in coordination among various businesses in the group. The risk concentration refers to the situation where a particular risk is accumulated by different parts of the group unknowingly and unintentionally and it later turns out to be excessive for the group in general. In the recent crisis, the US subprime loans were contained in various financial products, which later amounted unexpectedly to highly significant amounts for some financial groups. The conflicts of interest may arise when the group provides a variety of products or services for clients. In the financial context, the securities arm typically underwrites bond issuing of the client, for example, knowing that the client intends to use the raised funds to repay the loans from the banking arm. The risk of double gearing indicates that the same capital pool may be used multiple times for the regulatory assessments. In a further illustration of the point, the combined pool of capital belonging to the parent institution and its subsidiaries may be used in calculating the regulatory capital for both the parent and the subsidiaries. On a consolidated basis, the actual level of capital could in fact be far lower than calculated.

\section{Types of corporate and financial groups}

Corporate groups are incredibly diverse. Some groups consist of a few member companies, while other groups involve hundreds or even thousands of members. Corporate groups are formed on the controlling-controlled relationship, normally backed by majority shareholding in the case of stock companies. In some cases, however, the ultimate owner is able to exercise control over member companies with much smaller shareholding by use of the "pyramid" structure that contains multilayers within the controlling-controlled relationship. For example, where the ultimate owner has $60 \%$ of Company A, which has $60 \%$ of Company B, which has $60 \%$ of Company $\mathrm{C}$, the owner can control Company C effectively with $21.6 \%$ (=60\%x60\%x60\%) ownership.

In many corporate groups, there are one or several ultimate parent companies that oversee the whole group, although the degree of oversight ranges widely. Some ultimate parent companies are a pure holding company that specialises in controlling and managing subsidiaries, while others are an asset management company of a family that may or may not exercise active control over the group. Moreover, other ultimate parent companies engage in real businesses by themselves. For financial groups, such businesses may be financial or non-financial. Also, the ultimate parents may not be companies but individuals or states.

The ownership structure of controlled companies is also varied. They are normally the subsidiary majority-owned by the parent, while $100 \%$ owned in many cases. They may also be a joint venture on which more than one parent has control, or an associate company in which the investor (parent) has significant influence by way of holding a strategic portion of the shares ${ }^{1}$. The ownership structure of controlled companies is determined by business judgement of the (ultimate) parent, and may differ according to the strategic positions of the companies in a given group.

Large corporate groups often involve listed companies. They may be the ultimate parents, subsidiaries or both. The ultimate parents that manage family assets are normally private and unlisted, while many holding companies are public and listed. Where a subsidiary in a group is listed, the protection of minority shareholders draws a legal and regulatory attention.

1 The International Accounting Standards state that a holding of $20 \%$ or more of the voting power (directly or through subsidiaries) will indicate significant influence unless it can be clearly demonstrated otherwise (IAS 28.6). 


\section{Governance of corporate and financial groups}

It may not be necessary to consider the governance of corporate groups separately from the subject of corporate governance in general. The governance of the ultimate parent company cannot be too different from that of the headquarters of a large-scale enterprise with a number of departments and branches. The relationship between the parent and subsidiary can be regarded as a form of that of the company and its major shareholder. In fact, the new G20/OECD Principles of Corporate Governance issued in 2015 (referred to hereafter as the G20/OECD Principles 2015) do not differentiate corporate groups in particular, assuming they sufficiently apply to the companies in the group structure.

Yet, it may still be worthwhile to pay particular attention to the governance of company groups, for example, in order to deal with the idiosyncratic risks that group structure brings about. The governance of subsidiaries has great similarities with that of company branches, but there are considerable differences derived from the different legal status. Some guidelines for the governance of corporate groups can be identified as below.

Corporate governance of financial institutions may differ from that of non-financial entities mainly for two reasons. First, due consideration to the interests of stakeholders other than shareholders is of much more importance in the governance of financial institutions. Financial institutions normally have a number of unsecured creditors such as depositors and insurance policyholders, and they have the social responsibility to maintain sound and adequate management. Another important stakeholder is the financial supervisors, who have the mission to protect insured creditors, taxpayers bearing the bailout costs in case of insolvency, and the financial system as a whole. Second, financial businesses are intangible, and complicated and therefore present additional challenges to manage properly. Moreover, financial institutions need to pay close attention to reputation risk, which they are vulnerable to as their business depends upon public confidence, and also to the compliance risk as a broad range of special regulations and rules are applied to them.

The unique specifics of corporate governance of financial institutions are reflected clearly in examining financial groups. The managerial complexity may be aggravated for financial groups that hold a number of regulated and unregulated entities, and further for financial conglomerates that include the businesses of more than one financial sector. In this field, the international bodies such as the Basle Committee on Banking Supervision (BCBS) and the International Association of Insurance Supervisors (IAIS) as well as the OECD have relevant guidelines, which are attached here in the appendix.

\section{Composition of this article}

The rest of this article examines the corporate governance of corporate groups with particular attention given to financial groups. The next section provides the international perspective for corporate and financial laws on the governance of corporate groups. It finds that the legal approach varies among jurisdictions. The third section looks into the corporate governance at a group level. The intention is to identify good practices and regulatory consideration for group governance. In turn, the fourth section illustrates the corporate governance at a subsidiary level. The regulatory concern here is to ensure the soundness of financial subsidiaries. Then the governance and regulatory issues for the groups beyond the border are discussed in the fifth section. The final session concludes. 


\section{LEGAL FRAMEWORK FOR CORPORATE GROUPS}

\section{Corporate law landscape}

\section{Fiduciary duty of board directors}

Generally speaking, corporate groups should be managed holistically, like an enterprise, in order to fully benefit from the group formation. The headquarters at the ultimate parent home location oversee all the businesses within the group, develop the group-wide strategy and give directions to the member subsidiaries. The boards and management of the subsidiaries are expected to follow general or specific directions. They are practically obliged to do so, as the directions are backed by the parent's controlling power based on shareholding.

In contrast to this reality, many company laws around the world stipulate the fiduciary duty of board directors of a company that require them to act in the best interest of the company, not for the interest of the majority shareholder. In ordinary cases, the problem would not surface, as the interest of the parent or the group is generally aligned with that of the subsidiary. However, these interests can come into conflict occasionally, which then puts the subsidiary directors into a dilemma. Where they perceive that the direction of the parent is not for the best interest of the company, they need legally to refuse such a direction, otherwise they could face civil and criminal charges, although such refusal often seems unrealistic.

To date, various attempts have been made worldwide to address this subsidiary dilemma in the company law sphere. Reflecting the reality of corporate groups, the major attention has been directed to how to provide leeway for the parent company to manage the subsidiaries in the interests of the whole group. There appears to be essentially two different approaches for this: to give legitimacy to the directions by the parent company over its subsidiaries; and to recognise the interest of the group for which directors of the subsidiary can act.

\section{Legitimacy for directions by the parent over its subsidiaries}

The first approach is to establish the legal framework to permit the parent company to exercise directions over its subsidiary for the interest of the group or the parent. In return for this authority, the parent would bear the special liability for the loss incurred in the subsidiary by its influence, which provides the protection for the minority shareholders and creditors of the subsidiary.

The often cited jurisdictions taking this approach include Germany, which has a codified corporate group law for stock corporations. In the German law, two types of corporate groups are stipulated: contractual and de facto.

A contractual group is formed when the parent and the subsidiary enter into the contract that gives the parent the right to control the subsidiary. In a contract group, the management board of the parent can issue direct instructions to that of the subsidiary even if the instructions disfavour the subsidiary, as long as they serve the interest of the parent or the group and they do not threaten the existence of the subsidiary (Troeger 2014). Moreover, the parent has the obligation to compensate the net loss of the subsidiary annually, which provides protection for the interests of minority shareholders and creditors of the subsidiary. The minority shareholders are also protected by the right to sell out their shares to the parent at a fair price. In reality, however, contractual groups are rare in Germany (Hopt 2015). 
When the parent has effective control over the subsidiary without such a controlling contract, a de facto group is considered to form. In a de facto group, all acts and transactions induced by the parent that disadvantage the subsidiary must be reported, audited and fully compensated within a year. If the parent fails to compensate its negative influence over the subsidiary in a timely and appropriate manner, the parent and its directors are jointly and severally liable for the damages to the subsidiary. The claim can be brought by the management board of the subsidiary, and also by its shareholders as a derivative action (Troeger 2014). It is noted, however, that the effective functioning of this framework depends on the interpretation of the notions of "disadvantage" and "compensation" which may require time-consuming judicial decisions.

The German model has been followed, to a greater or lesser extent, by many other European countries such as Portugal, Slovenia, Croatia and Albania. By contrast, Austria and Poland have not chosen this approach despite that their legal tradition is similar to that of Germany (EMCA 2015). Outside Europe, Brazil and Turkey have similar legal frameworks for corporate groups.

Another example is Italy, which has introduced a special regulation for corporate groups in its Civil Code in 2004. Under the regulation, when a parent company exercises direction or coordination in its subsidiary company and acts against the entrepreneurial interests of the subsidiary company, the parent company is directly responsible to the shareholders of the subsidiary company for any resulting loss of income or loss of the value of their shares. The parent company is also liable to the creditors of the subsidiary company for damage caused to the integrity of assets of the subsidiary (Andenas and Wooldridge 2009). Though appearing to be influenced by German law, the Italian regulation is considered to be more flexible than German one (EMCA 2015). Czech Republic had the German-type legal framework, but the new Corporations Act in 2012 allows more flexibility in the management of corporate groups.

\section{Recognition of the interest of the group}

The second approach to address the legal dilemma of subsidiary directors is to allow them to act in the interest of the group. This approach has been developed mainly in the courts. The most cited example is the so called "Rozenblum" doctrine derived from the French Supreme Court decision in 1985. In the decision, the court recognised the interest of the corporate group and admitted a "group defence" in the criminal case of the abuse of corporate assets (abus de biens sociaux), which is often used against selfdealing. Such a "group defence" can stand when the following conditions are satisfied: i) the group is characterised by capital links between the companies; ii) there must be strong, effective business integration among the companies within the group; iii) the financial support from one company to another company must have an economic quid pro quo and may not break the balance of mutual commitments between the concerned companies; and iv) the support from the company must not exceed its possibilities, or in other words, it should not create a risk of bankruptcy for the company (Conac et al 2007).

Other European countries, such as Belgium, Luxemburg, the Netherlands and Nordic countries, follow this approach.

\section{No special considerations to corporate groups}

Unlike the jurisdictions mentioned above, the United Kingdom has neither a special legal framework for corporate groups nor a court law comparable to the "Rozenblum" doctrine. Traditionally the United Kingdom adheres to the concept of fiduciary loyalty of directors to the company, and its courts have upheld firmly the principle of separate legal entity. Therefore, the governance issues associated with corporate groups are also dealt with by the general corporate law provisions applied to standalone companies. However, this does not mean that directors of a subsidiary company cannot take into 
consideration the interest of the group or the parent in their decision making. Section 172 of the Companies Act 2006 stipulates that a director of a company must have regard to various factors including the likely consequences of any decision in the long term. In reality, the conclusions derived from the UK approach might not be very different from those of the French approach.

In many other jurisdictions, including the United States and Japan2, no statutory or court laws to permit subsidiary directors to act just in the interest of the group have been established. Their fiduciary duty is directed only to the company or its shareholders as a whole, not to the majority shareholders or the group. It should be pointed out, however, that subsidiary directors may be protected by the business judgement rule presumption in their decision making taking the interest of the group into consideration (OECD 2015c).

Having the similar legal tradition with the United Kingdom, Australia also has no comprehensive framework for corporate groups in its Corporations Act 2001. However, the Act has the provision concerning the parent-subsidiary relation which applies only to wholly-owned subsidiaries. The Section 187 of the Act permits a director of wholly-owned subsidiaries to act in good faith in the best interests of the holding company, if the constitution of the subsidiary expressly authorises it, and the subsidiary is not insolvent or does not become insolvent because of the act.

\section{Protection of subsidiary creditors ${ }^{3}$}

A subsidiary company is an independent entity that holds rights and duties on its own. The shareholders of a limited liability company, including the controlling parent, do not have liability beyond the amount invested in the company. Although the parent often provides financial support to its subsidiary in distress to protect the interest of the group as a whole, it may let the subsidiary go bankrupt when the parent considers it appropriate. In such cases, the creditors of the subsidiary cannot make claims directly to the controlling parent in principle. While subsidiary creditors also benefit from the measures for minority shareholder protection, they need to look after themselves by seeking collateral not only from the subsidiary but also from the parent when necessary.

In many jurisdictions, however, some mechanisms have been developed to hold the controlling parent liable for the subsidiary creditors, though the actual cases are limited. First, when a limited liability company is in the vicinity of insolvency, the fiduciary duty of its directors could be enhanced to include possible efforts to protect its creditors. The directors could be liable for their wrongful conduct in this regard, including for negligence. In this context, the controlling parent could be liable if it is regarded as "de facto director" or "shadow director" of the controlled subsidiary. The conditions for treating the parent as these directors vary between jurisdictions. The UK Companies Act stipulates that a body corporate is not to be regarded as a shadow director of any of its subsidiary companies by reason only that the directors of the subsidiary are accustomed to act in accordance with its directions or instructions. ${ }^{4}$ The French courts treat the parents as "de facto manager" when they mix themselves in the management and control of the subsidiary.

Second, in many jurisdictions the doctrine of "piercing the corporate veil" is also used. It treats the liability of the limited liability corporation as being held directly by the controlling shareholder. As it stands against the general principle of limited liability, the courts apply it for very limited cases such as

2 Japanese Companies Act 2005 stipulates the responsibility of the board of directors to develop systems necessary to ensure the properness of operations of the company and operations of group of enterprises consisting of the company and its subsidiaries (Article 362). However, this provision is not normally interpreted to provide the legal authority for the controlling company to exercise directions over its subsidiaries, nor for the boards of the controlled subsidiaries to follow such directions.

3 This part draws substantially on Hopt (2015).

4 Section 252 (3) of the UK Companies Act 2006. 
where the corporation is created for a fraud purpose. It has been rarely used in Europe but more frequently applied in the United States.

Third, in the group law established in such jurisdictions as Germany, the parent and its directors are jointly and severally liable for the damage of the subsidiary incurred by their influence unless it is not adequately compensated by the parent, which may serve as protection for subsidiary creditors. Moreover, many countries have the mechanisms to protect subsidiary creditors in their insolvency law. For example, in the insolvency proceedings, the claims of controlling shareholder are subordinated to those of other creditors. In some jurisdictions, the insolvency courts can consolidate the proceedings of the member companies of a group, merely procedurally or substantially.

\section{Financial law perspective}

\section{Financial regulation for financial groups}

Given their social responsibility to maintain sound management for numerous creditors, financial institutions including inter alia banks and insurers, are subject to special regulation. And so are financial groups which contain such institutions within, as the group or its ultimate parent has a significant influence on the sound management of member financial institutions. For example, the Principles for the supervision of financial conglomerates published by the Joint Forum in September 2012 (referred hereafter as Joint Forum Principles 2012) start with the first principle stating: The legal framework for the supervision of financial conglomerates should grant supervisors (including the Group-level Supervisor) the necessary powers and authority to enable comprehensive group-wide supervision (Principle 1).

Various financial regulations concerning the corporate governance of financial groups are touched upon in the following sections. This part focuses on the legal relationship between the controlling parent and the controlled financial institutions.

\section{Parent responsibility for a financial subsidiary}

As described above, in principle, the controlling parent is not legally responsible for the subsidiary debts. It does not have the obligation to assist the subsidiary in financial distress. Nevertheless, many jurisdictions have financial regulations that require the controlling parent to ensure the soundness of its financial subsidiaries and to support its financial subsidiary in financial difficulty when necessary. The creditors of subsidiary financial institutions, inter alia depositors or policyholders, are protected by such regulation although they may not have the civil right to claim to the parent.

In Japan, for example, the Financial Services Agency has the authority to order the financial holding companies to take necessary measures to secure sound and adequate management of the subsidiary banks and insurance companies. The Agency also has the same authority for the other controlling shareholders with the majority voting rights of banks and insurance companies. The breach of the order will be subject to an administrative fine and lead to further supervisory actions.

In the United States, the appropriate Federal banking agency may require the bank holding company or any other company that directly or indirectly controls the FDIC insured depository institution to serve as a "source of financial strength" for such institution. The "source of financial strength" is meant to be the ability of the group to provide financial assistance to the insured depository institution when the institution is in financial distress. This idea is backed by the observation that a person may become a depositor of a subsidiary bank of a large group implicitly believing the group's financial strength stands behind it (Lumpkin 2010). 


\section{CORPORATE GOVERNANCE AT A GROUP LEVEL}

\section{Overview}

The establishment of effective corporate governance at a group level is essential for the group as a whole in order that they enjoy the maximum benefits of doing various businesses in group structure while minimising the associated risks. The challenges are fundamentally similar to the governance of large-scale enterprises with a number of departments and branches, but they may be more complicated because unlike branches, subsidiary companies are separate legal entities that have their own boards, and also frequently minority shareholders and creditors, whose interests could be different from the interest of the group.

The group-wide governance policy can conceptually take two directions: centralise or localise. The centralised governance model intends to operate subsidiaries like branches of the parent. The parent directly oversees and controls the operations of subsidiaries. The localised model delegates the oversight and control functions to the subsidiary boards. Each subsidiary is autonomously managed by its board that takes into account the interest and strategy of the group.

The centralised governance model may seem effective and efficient for the integrated management of member companies to reap the maximum benefits of doing various kinds of businesses in group structures. However, as the group structure is more complex with a larger number of subsidiaries, the centralised control becomes more difficult while localisation seems inevitable for effective control. In reality, ultimate parents need to strike a balance between the two models, suitable to their corporate group, and also to adjust the balance according to the changes in the group businesses. The balance could also vary within a group. The smaller subsidiaries doing the business directly associated with the parent's may be subject to the centralised control, while the larger and more remote subsidiaries may enjoy more independence in its management.

When the subsidiary governance is localised, the policy and process of determining how to align it with the group-wide interests should be a key concern of the ultimate parent. There are various practices for this purpose, some of which are illustrated below.

For the governance of financial groups, financial regulation is of critical relevance. In essence, its attention is directed at ensuring the sound management of subsidiary financial institutions to protect their depositors and policyholders, and the financial system as a whole. With such regulation, the governance of financial groups requires some additional considerations.

With regards to the governance of financial groups, financial regulation seems to be structured according to two different strategies concurrently. On one hand, it stresses the responsibility of the controlling parent. For example, the BCBS Corporate governance principles for banks issued in July 2015 (referred hereafter as BCBS Principles 2015) specifies: In a group structure, the board of the parent company has the overall responsibility for the group and for ensuring the establishment and operation of a clear governance framework appropriate to the structure, business and risks of the group and its entities (Principle 5). On the other hand, in response to the recent global financial crisis, many jurisdictions tend to place more emphasis on the independence of subsidiary financial institutions in their own territory.

The following parts of this section enumerate various considerations for effective governance of corporate groups, with a particular attention on that of financial groups. The caveat here is that there is no 
"one size fits all" solution for effective group governance, as corporate and financial groups are significantly diverse in their structures, strategies and businesses. The considerations below should be adapted to the reality of the groups.

\section{Group structure}

\section{Understanding of the group and its members}

The first step for effective group-wide governance should be that the board and senior management of the ultimate parent understand clearly the structure of the group: the businesses of member companies, their ownership structures and jurisdictions, etc. It is not an easy task when the group has a multitude of members within a multi-layered ownership structure across borders.

In the international accounting standards, the list of subsidiaries is required to be identified and disclosed in the consolidated financial statements of the controlling parent. However, this requirement essentially covers the subsidiaries that the parent controls directly. For governance purpose, the board and senior management of the ultimate parent should grasp a much broader, comprehensive picture of the members in the group. In this regard, it may be advisable that the ultimate parent develop an integrated database of member companies of the group (Frederick 2014).

The structural complexity of a corporate group is a major source of the governance risk. The board and senior management of the ultimate parent should maintain updated knowledge of the member companies and occasionally review the group structure. In order to avoid excessive complexity, they may need to put control on creation of new subsidiaries, for example through the parent approval procedure, and to dissolve the subsidiaries that have finished their missions. ${ }^{5}$

\section{Considerations for financial regulation}

Clear understanding of the group and its members by the ultimate parent is equally important for the effective governance of financial groups. The BCBS Principles 2015 state: The board and senior management [of the parent company] should know and understand the bank group's organisational structure and the risks that it poses (Principle 5). The OECD Guidelines on Insurance Governance issued in 2011 (referred hereafter as OECD Guidelines 2011) also specifies more generally: [Group] ownership, structures, arrangements and relations ... should be well understood by boards of directors and key executives (III. A.).

Moreover, it is required that the structure of financial groups be transparent and understandable particularly for the financial supervisors. In order to conduct effective supervision, the supervisors need to know who the ultimate controlling parent is, how the managerial responsibilities are divided between the parent and the financial subsidiary, how the management of the financial subsidiary is influenced by the parent and other members of the group, and so on. The IAIS Insurance Core Principles updated in November 2015 (referred hereafter as IAIS ICP) state that at a minimum, the applicant [for insurance license] is required to have a corporate or group structure that does not hinder effective supervision (par 4.3).

Where the group structure is too opaque or complex for proper supervision, the supervisor should be able to require restructuring of the group structure. For example, the Joint Forum Principles 2012 mention:

$5 \quad$ BCBS Principles 2015 provide practical guidelines to avoid or mitigate the challenges arising from the complex or opaque structure of financial groups (par. 102). 
Supervisors should seek to ensure that the structure of the financial conglomerate does not impede effective supervision; and Supervisors may seek restructuring under appropriate circumstances to achieve this, if necessary (Implementation criteria 11(c)).

It should also be noted that doing certain types of financial business, especially commercial banking and insurance undertaking, is normally permitted exclusively to authorised entities, and these entities as well as their subsidiaries are subject to the restriction that prohibits them from engaging in unauthorised businesses. Such segregation regulation attempts to insulate these entities from other business risks than those emerging from their own financial activities. This indicates that financial regulation seeks the independence of regulated financial entities even in a group structure. Therefore, where these entities are part of a wider business group, its parent is required to respect the independence of the financial subsidiaries to protect them against unfavourable influence from other parts of the group including the parent itself.

The segregation regulation, which seeks to avoid mixing different sorts of business risks, may also be applied within the financial sector. For example, banking and insurance undertaking should be conducted by different legal entities. In many jurisdictions, an insurance company may not undertake both life and non-life insurance. In response to the recent global financial crisis, some jurisdictions have launched the institutional separation of retail deposit taking and investment banking. For example, the UK Banking Reform Act of 2013 set forth the regulation to limit the deposit taking activity to "ring-fenced bodies" that are prohibited from carrying on dealing in investments as principal. The Act requires "ring-fenced bodies" to be highly independent of other members of its group in decision making, transactions and governance (board composition, etc.). The US Dodd-Frank Wall Street Reform and Consumer Protection Act of 2011 stipulated the so-called "Volcker rule", which bans insured depository institutions and their affiliates from proprietary trading.

\section{Parent board and senior management}

\section{Suitability of board members and senior managers}

The board and senior management of the parent of a corporate group need to exercise adequate oversight and control throughout the group. To discharge their duties, the board and senior management should be composed of individuals that hold sufficient skills, expertise and diversity as a group to deal with the complexity of the group businesses.

In the case of financial groups, the financial supervisors need to be satisfied of the suitability of the parent board members and senior managers. With regard to financial holding companies, the financial supervisors in many jurisdictions have the authority to approve the appointment of their board members and senior managers. The so-called "fit and proper test" is carried out by the supervisors to ensure their suitability. Moreover, the significant ownership is often subject to the approval of the relevant financial supervisor, especially to verify the qualifications of the owner, which may include the composition of the board and senior management in case of a corporate owner.

\section{Independent board members}

Today, having a sufficient number of independent board members is generally regarded as a good corporate governance practice. The G20/OECD Principles 2015 emphasise that the board should be able to exercise objective independent judgement on corporate affairs, and that board independence in these circumstances usually requires that a sufficient number of board members will need to be independent of management (VI. E.). For banks and the parents of banking groups in particular, the BCBS Principles 2015 specify that the board should be comprised of a sufficient number of independent directors (par. 47). 
The independence should be defined by national regulation. In general, independent board members are those who are not employed by the company or its affiliates and not closely related to the company or its management through significant economic, family or other ties, while independence from controlling shareholders or another controlling body need to be emphasised in case where, for example, the protection of minority shareholders is of importance (OECD 2015b). The "sufficient number" should also be defined, which differs among jurisdictions and often depending on the nature of the company (e.g. listed or not listed). The Institute of Luxembourg Directors suggests that to be effective, boards should have at least two independent members, so as to avoid depending on a single independent director to act as a whistleblower in board meetings in case of wrongdoing or minority shareholder abuses (ILA 2015). Independent board members should also be able to share views among themselves.

\section{Remuneration policy}

It has been argued that the remuneration and incentive schemes for the board directors and senior managers of banks contributed to the recent financial crisis by encouraging them to take riskier actions. Remuneration has been associated with corporate performance in the financial sector as well as other sectors, often including granting shares or stock options in significant amounts. With a relatively short vesting period for the stock options, the directors and senior managers may be incentivised to seek shortterm profits, paying less attention to the risks in the long term (Mehran et al 2011).

Rationally, taking a sufficient risk in business is aligned with the interest of shareholders, but not necessarily with that of creditors who want to minimise the default risk. For the financial institutions which have numerous creditors including depositors or policyholders, the board directors and senior managers should take the interest of such creditors into due consideration, and their remuneration policies should be designed accordingly.

The remuneration policies for the board directors and senior managers of financial groups and their parents should also be structured so that such directors and managers have respect for the interest of depositors or policyholders of their subsidiary financial institutions, as such directors and managers have potential influence over the management of the subsidiaries. The Joint Forum Principles 2012 mention: Supervisors should require that the financial conglomerate has and implements an appropriate remuneration policy that is consistent with its risk profile (Principle 14).

\section{Board committees}

Given the significant responsibilities of the board, the specialised committees are often set up under the board to support the work of the board. With a focus on particular areas, the committees can carry out their functions effectively and efficiently, which enhances the overall board performance. It is particularly true for the boards of parent companies that need to oversee the operations of various group constituencies. It is common today that the boards of large financial groups have the specialised committees, although the committee structure and responsibility differ according to the nature and size of the businesses as well as local regulations.

When considering to set up board committees, normally first comes the audit committee, which is particularly responsible for the internal audit function and the financial reporting integrity. Also very common are the risk management and compensation committees. Moreover, the BCBS Principles 2015 recommend banks and the parents of banking groups to establish the nomination/human resources/governance committee and the ethics and compliance committee (par. 77). Besides, today an increasing number of internationally active financial groups also establish the board committee on social responsibility, such as the philanthropic and community investment oversight committee (HSBC 
Holdings), the responsible business committee (Lloyds Banking Group), and the corporate responsibility committee (UBS Group).

When the specialised committees are set up, the G20/OECD Principles 2015 stress that their mandate, composition and working procedures should be well defined and disclosed by the board (VI. E. 2.). The BCBS Principles 2015 also state: Each committee should have a charter or other instrument that sets out its mandate, scope and working procedures. This includes how the committee will report to the full board, what is expected of committee members and any tenure limits for serving on the committee (par. 64). In addition, the latter Principles point out that a committee chair should be an independent, non-executive board member (par. 67). Similarly, the IAIS ICP mentions: Where committees are appointed, they should have clearly defined mandates and working procedures (including reporting to the Board), authority to carry out their respective functions, and a degree of independence and objectivity as appropriate to the role of the committee (par. 7.3.6).

\section{Group-wide integrity, policies and culture}

Corporate groups may consist of various member entities that can have different ownership structure, nature and size of business and operations, risk profiles, autonomy and so on. The governance arrangements for respective member companies should be developed by the boards and senior management of the ultimate parents, which have the ultimate responsibility for the management and governance of the groups as a whole.

Although the practical governance arrangements may differ according to the characteristics of member entities, the board and senior management of the ultimate parent should establish the integrity in the governance of the group. For this purpose, the group-wide policies should be developed by the parent board and then shared by all member entities. Such group policies may include: strategic objectives, corporate value, corporate governance principles, codes of conduct and ethics, risk management framework, remuneration, social responsibility, and so on.

It should also be pointed out that the corporate culture of good governance is a critical component for the governance of group entities (Mak and Bennett 2014). Properly written group policies should provide a base for developing such culture. Moreover, the board and senior management of the ultimate parent should undertake to "set the tone" for such culture by demonstrating their commitment to good governance by their daily behaviour. After all, good corporate governance depends on constituent individuals of the group. The propagation of the clear group policies across the group and training of key persons in the member entities should contribute to developing good governance culture and practices in the group.

The group-wide integrity, policies and culture are no less important for financial groups that have the ultimate responsibility in the sound management of their financial subsidiaries. For example, the Joint Forum Principles 2012 stress the importance that the financial conglomerate establishes a comprehensive and consistent governance framework across the group that addresses the sound governance of the financial conglomerate (Principle 10). The Principles also specify: Supervisors should require that the financial conglomerate emphasises a high degree of integrity in the conduct of its affairs (Implementation criteria $10(b))$.

\section{Strategy and decision making}

In order to operate a corporate group effectively and efficiently, the board of an ultimate parent needs to establish a group-wide strategy, which then cascades down to subsidiary-level strategies. How to formulate the subsidiary-level strategies can vary in practice. Under the centralised governance model, the 
ultimate parent board (or its management) may set up the subsidiary-level strategies based on the groupwide strategy, which should be implemented by the subsidiaries. By contrast, under the localised model, the ultimate parent may require significant inputs from the subsidiary boards in forming the subsidiarylevel strategies, or even ask them to draft such strategies for its approval. In any case, the boards of ultimate parents should make sure that subsidiary strategies are well in line with the group-wide strategy.

While subsidiary boards are responsible for the daily decision making in their business, important business judgements need to be made at the parent-level. Subsidiary boards may rely on the parent for decision making, or ask for its approval on their proposals. On some important issues, such as sales of significant assets, the parent approval is often legally required in the form of a resolution of the shareholders meeting. Nevertheless, a much wider range of issues are normally subject to the parent judgement in a corporate group, though the range differs among the groups and the subsidiaries in a given group. In addition, a parent may want reporting from subsidiaries on some issues though they may not need the parent judgement or approval.

For good governance of a corporate group, it is essential to set up the standards or guidelines to identify which issues at the subsidiary level should be subjected to the parent's judgement or reporting to the parent. The formal procedure for requesting the parent judgement or reporting should also be established. Such standards or guidelines contribute to clarifying the responsibilities of both subsidiary and parent boards, which should reduce the risk of mismanagement of the subsidiary. One may argue that such standards or guidelines are unnecessary when the director or senior management of the parent sit at the subsidiary board. Even in such cases, however, these standards or guidelines are useful in providing the guidance for these subsidiary directors to act properly.

In principle, the same considerations should apply to financial groups. The Joint Forum Principles 2012 specify: Supervisors should require that the board of the head of the financial conglomerate appropriately defines the strategy and risk appetite of the financial conglomerate, and ensures this strategy is implemented and executed in the various entities, both regulated and unregulated (Principle 13). Moreover, the OECD Guidelines 2011 mention: A coherent, well-functioning and transparent governance system should be established within the group to ensure sound governance practices, with clear lines of responsibility and accountability across the group consistent with applicable legal requirements (III. C.). Similarly, the IAIS ICP underlines: Within a group the allocation and division of the oversight and management responsibilities at different levels should be transparent, appropriate for, and aligned with, the organisational model of the group (par. 7.1.3).

\section{Control and oversight}

\section{Control and oversight of corporate groups}

The board and senior management of the ultimate parent are responsible for oversight of the management not only of the parent company but also of all group entities. In reality, a failure at a subsidiary level could lead to severe financial loss and reputational damage for the group as a whole. However, how to monitor the businesses of subsidiaries and control their associated risks at the parent level is a significant challenge for the parent, especially when the group has a complex ownership structure with a number of subsidiaries in multiple layers and locations.

The first line of defence is the subsidiaries and in particular their boards, who have the primary responsibility for their operations. The appointment of the board members should be carefully considered while taking into account the nature, size and other features of the subsidiary. The practical group-wide governance policies are imperative to guide them adequately. Communication is of importance in this 
regard. Reporting procedure should be established. Large and complex group may benefit from setting up a unit at the parent that specialises in monitoring the governance practices of group entities.

\section{Risk management, internal control and compliance}

The second line of defence against mismanagement in a corporate group is a group-wide risk management system. The G20/OECD Principles 2015 recognise: An area of increasing importance for boards and which is closely related to corporate strategy is oversight of the company's risk management (VI. D. 1.). Undoubtedly this applies to corporate groups and their boards, as the boards may need to cope with a broad range of risks involved in different businesses run in the groups.

In the case of financial groups, further importance should be placed on risk management. Where the group contains multiple financial institutions, the combined risks could be more concentrated, affecting the soundness of the group as a whole, or they could be more diversified to provide additional risk taking capability. Therefore, integrated risk management at a group level is required. The BCBS Principles 2015 specify that in banking groups, there should be a group CRO (chief risk officer) in addition to subsidiarylevel risk officers (par. 108).

In addition to a risk management function, internal control mechanisms and compliance functions are key components of an effective governance framework for financial groups as well as financial institutions. The internal control mechanisms at a group level are necessary to adequately handle various conflicts of interest arising from the group structure including a range of different business entities. Such conflicts of interest may be found in two types of transactions: the first concerns intra-group transactions between member entities, and the second relates to the situation where different entities face one client (for example, a client lends money from a member bank to buy an investment product from another member asset manager). The compliance function is also important for financial entities that face significant regulatory and reputational risks.

The Joint Forum Principles 2012 state: Supervisors should require that the board of the head of the financial conglomerate has overall responsibility for the financial conglomerate's group-wide risk management, internal control mechanism, internal audit and compliance functions to ensure that the group conducts its affairs with a high degree of integrity (Implementation criteria 21(e)). Also, the OECD Guidelines 2011 specify: The control functions of the controlling entity in the group should appropriately consider a group-wide perspective in their activities and support, as appropriate and as may be requested, the control functions within controlled entities (III. C.).

Accordingly, many financial groups organise these functions in a centralised way. Typically, at the parent level, the board committees responsible for risk management, internal control and compliance are set up, and the group-wide functional units to support these committees are established. However, the central units at the parent level alone may not be able to perform effectively and efficiently, as for example, risk management or compliance function may require substantial local knowledge. It should also be noted that financial regulation normally requires these functions to be conducted by individual financial institutions. Consequently, financial groups with large-scale financial subsidiaries need to establish the control functions both at parent and subsidiary levels. To be effective and efficient, such financial groups need to identify and build an adequate structure and procedure for these functions.

\section{Internal audit}

The third line of defence is a group-wide internal audit system to detect risks and problems at subsidiaries. Its structure can vary. An integrated unit at the parent level may be created to examine the business activities of all subsidiaries. A network of the parent and subsidiary audit functions may be 
established so that a problem detected by a subsidiary auditor be reported directly to the parent auditor and then to the parent board. The combination of these structures is also possible and popular for the internationally active financial groups. For example, HSBC Holdings and UBS Group have Global Internal Audit, which is a centralised, independent function to perform internal auditing for the entire group. Three large banking groups in Japan also establish the group-wide internal audit function at the parent as well as the local audit functions at major subsidiaries. When designed to function effectively, the group-wide internal audit would play a critical role in helping the ultimate parent identify risks and misconducts at the early stage and deal with them before they become fatal for the group.

In addition to internal audit, financial audit provides the similar function from the financial accounting perspective. In many cases, financial audit function is integrated at a group level to produce the consolidated financial reporting.

Another measure for detecting problems is a whistle-blower system. It can be set up group-wide to facilitate the parent board's access to such information concerning a subsidiary. 


\section{CORPORATE GOVERNANCE AT A SUBSIDIARY LEVEL}

\section{Responsibility of subsidiary boards}

Subsidiary companies in a group operate under the influence of the parents with the majority ownership. Subsidiary boards are, more or less, subject to the directions of the parents. Nonetheless, company law normally stipulates that a subsidiary company is a separate entity and that its board members have the duty of loyalty to act in the best interest of the company and the shareholders as a whole, not of the majority shareholder.

Where a subsidiary is wholly owned by the parent, no conflicts exist with respect to shareholder rights because the parent represents the shareholders as a whole. The subsidiary board should be loyal and responsible only to the parent other than the company itself. The parent may or may not give autonomy to the subsidiary board. In accordance with the governance strategy set by the parent, the subsidiary board can act simply in the interest of the parent. In practice, the total shares of the subsidiary may not be held by the parent company alone, but shared by a group of associated legal and natural persons including the parent.

Where a subsidiary has minority shareholders other than the parent, the potential conflicts of interest come more strongly into play. The subsidiary board should act in the interests of all shareholders including minority ones. In spite of strong influence of the parent, the subsidiary board needs to take the interest of minority shareholders into account. When the conflicts of interest between the parent and minority shareholders arise, the board has to handle them in an adequate manner to treat all shareholders equitably. Where minority shareholders holds a sufficient number of shares to have a veto at the shareholders meeting, the board may need to pay particularly due attention to their interest.

Moreover, where subsidiary shares are listed at an exchange, the subsidiary board is subject to securities market law and regulation. Such requirements are generally designed to ensure the protection of minority shareholders, and may seek to ensure the larger responsibility of the listed subsidiary board in its governance arrangements. Under market law and regulation, the board of listed subsidiaries may be required to perform strictly their fiduciary duty to act in the interest of the company. In cases where the direction by the parent conflicts with the regulation, the subsidiary board is obliged to follow the latter.

Another type of ownership is joint ventures, which typically have a few major shareholders. In general, their governance framework differs from other subsidiaries by the fact that they belong to more than one group simultaneously. In joint ventures, the investor-owners normally have their representations at the governing boards to develop the strategy and oversee its implementation. Therefore, the major responsibility of the governing boards is to coordinate the interests of major shareholders.

Lastly, financial subsidiaries are subject to financial regulation. The subsidiary boards may not be loyal to the supervisors but should follow the regulation. With supervisory objectives to protect a multitude of creditors, inter alia depositors or policyholders, taxpayers who may suffer from bailouts of financial institutions and the financial system, the financial regulation puts the primary importance on the soundness of each financial subsidiary, and thereby looks for more responsibility of the subsidiary and its board in its governance framework and practices. This regulatory preference for greater independence of financial subsidiaries may create tension with financial groups that seek to establish more integrated management. 


\section{Role of subsidiary boards}

\section{Role of subsidiary boards in a corporate group}

In reality, the role of subsidiary boards varies significantly among and within corporate groups. At one end of the spectrum, where a subsidiary is effectively integrated into the parent's operations and is treated like a division or branch of the parent, the role of its board should be quite narrow. It could be limited sometimes only to rubberstamping directions from the parent. In fact, the board of a wholly-owned special purpose corporation often serves only a token purpose. At the other end, where a subsidiary is given a high degree of autonomy and managed like a standalone entity, the role of the subsidiary board should not be much different from that of an independent company's board.

In general, the fundamental responsibility of company boards includes strategy setting and management monitoring. In a corporate group structure, the strategy setting function is normally conducted centrally by the parent boards in order to manage effectively and efficiently the group as a whole. In consequence, the subsidiary boards principally have a limited role in this function. Nonetheless, the subsidiary boards, especially of the important entities in the group, should contribute to the strategy setting by the parent boards with inputs of material information on business environments and so on. Particularly the subsidiary boards are often expected to play a role in formulating the subsidiary-level strategies, for example by providing significant inputs or by drafting them for the parent approval.

The primary function of the subsidiary boards is therefore management monitoring. The actual functions of the subsidiary boards depend on the governance frameworks set by the parents. The key components of the governance framework include: appointment, evaluation and removal of senior managers; risk management; internal control; compliance; and internal audit. These functions may rest with the subsidiary boards, or may be centralised in the parent boards or management. It should be noted that some functions, such as risk management and compliance, require significant understanding of local operations. Excessive reliance on the central function can invoke risk.

\section{Role of the boards of financial subsidiaries}

Even in group structure, the board and senior management of financial subsidiaries must still address their direct responsibility for the sound management of their entities. In order to ensure the protection of a multitude of unsecured creditors, financial regulation calls for the strict responsibility of the financial subsidiary boards in management and governance, although it should recognise the extent of autonomy can differ among the subsidiaries. For example, the Joint Forum Principles 2012 mention that the board of a regulated subsidiary of a financial conglomerate will retain and set its own corporate governance responsibilities and practices in line with its own legal requirements or in proportion to its size or business (Explanatory comments 13.2). Similarly, the OECD Guidelines 2011 specify: [The group-wide] governance system should recognise the responsibility of the board of any insurer within a group to exercise independent decision-making and ensure the soundness and performance of the insurer (III. C.).

Even in the policy setting, the boards of financial subsidiaries are expected to act adequately in order to give priority to their sound management. The BCBS Principles 2015 claim: the subsidiary board should make necessary adjustments where a group policy conflicts with an applicable legal or regulatory provision or prudential rule, or would be detrimental to the sound and prudent management of the subsidiary (par. 98). In particular, the board of the significant subsidiary should take such further steps as are necessary to help the subsidiary meet its own corporate governance responsibilities and the legal and regulatory requirements that apply to it (par. 99). 
Moreover, the Principles state clearly: Subsidiary boards and senior management remain responsible for developing effective risk management processes for their entities (par. 97). The OECD Guidelines 2011 point out: The essential components of the control functions of an insurer within a group should be retained, permitting independent oversight of the insurer's operations and the identification and mitigation of contagion risks (III. C.). In fact, large subsidiary financial institutions normally establish their own risk management, internal control and internal audit functions, and often have boards with audit and other specialised committees.

These principles indicate that financial regulation assigns responsibility to the boards of financial subsidiaries. Nevertheless, they also recognise the need of proportionality to the nature, size and risks of the operations in regulatory applications. Naturally, the larger the scale of operations of a financial subsidiary, the more responsibility the financial regulation may require the subsidiary board to assume. By contrast, where the financial operations are minimal and their influence beyond the group is fairly limited, the supervisors may be satisfied with adequate control by the parent.

\section{Subsidiary board composition}

\section{Characters of board directors}

Generally speaking, directors of subsidiary boards can fall into three categories: parent-related, local and independent. One individual may have two of these characters, although the first and the third are not normally compatible.

The parent-related directors are board directors, executives and senior staff of the parent (or other member) companies sitting at the subsidiary boards. Their relatives and those who had these statuses in the past as well as the ultimate individual owners and their relatives may also be included. The parentrelated directors are likely to manage the subsidiary for the interest of the parent and the group that they are familiar with. Especially when the parent intends an integrated governance approach for the subsidiary, its board may consist solely of such directors. Also, one may argue that by using their connections with the head of the group, the parent-related directors can pursue the interest of the subsidiaries reflected in the group-wide strategy at the parent level. It is not unusual around the world for board directors to have their seats both at the parent and the subsidiaries. In case of a significant localised governance approach, the holding company may have the board consisting of the CEOs of the major subsidiaries.

The local directors are of importance where the business of the subsidiary should be operated carefully in the local context. Savvy about local rules and practices, they can not only exercise effective oversight and management, but also contribute to local compliance. In some jurisdictions, the appointment of at least one local director is legally required.

The independent directors can play a pivotal role in the accountability of subsidiary companies. The directors independent of the parent are of particular importance when the company has minority shareholders. By bringing objective, unbiased perspectives in the board discussion and decision making, such directors can contribute to the board in ensuring the equitable treatment of shareholders and safeguarding the minority interests against abusive related party transactions. For this purpose, the laws and the codes in most jurisdiction call for some board members to be independent of dominant shareholders (OECD 2015b). Similarly, the securities market regulation often requires one or more such directors for listed subsidiaries.

Moreover, the non-executive directors independent of local management are valuable especially where the subsidiary has strong autonomy. Such directors should contribute to enhancing the accountability of the subsidiary management by providing the board meetings with inputs that are not 
locally biased. A caveat on independent directors is the possibility that they may stay loyal to the parent that selects them for the post, or the local management that they have various connections with. Independent directors function well only when they realise their responsibilities with objective judgement.

\section{Financial regulation on subsidiary boards}

From the financial regulatory point of view, the boards of financial subsidiaries, like other financial institutions, should have the primary responsibility to ensure sound and prudent management. Where the group policy conflicts with such management, the boards should act to give a priority to the latter rather than the former. The board members of financial subsidiaries should have independence from the parent to make this possible, while the parent may wish to appoint persons with loyalty to the group as board members of all subsidiaries. The Joint Forum Principles 2012 state: Supervisors should require ... the board of the head of the financial conglomerate include a number of members acting independently of the wider group (including owners, board members, executives, and staff of the wider group) (Implementation criteria $12(c))$.

The board independence can be supported by the directors who are independent of the parent. The BCBS Principles 2015 specify that the board should be comprised of a sufficient number of independent directors (par. 47). The boards of financial subsidiaries should not be the exception. Furthermore, the Principles mention: In cases where board members are selected by a controlling shareholder, the board may wish to set out specific procedures or conduct periodic reviews to facilitate the appropriate discharge of responsibility by all board members (par. 56).

The board of financial subsidiaries, as well as other financial entities, should be composed of individuals that hold sufficient skills, expertise and diversity as a group to fulfil its responsibilities adequately. In many jurisdictions, to make sure of the proper qualifications and composition of the boards and management of the financial entities such as banks and insurers, the financial supervisors carry out the "fit and proper test" of the directors and senior managers. The subsidiary board independence of inter alia the parent may also be verified in this test.

\section{Related party transactions}

\section{Intra-group transactions}

The governance concern for a subsidiary company comes up typically when it is required to enter into a transaction with other member entities in the group, which serves the interest of its parent or group to the detriment of the company. The conflicts of interest between the subsidiary and its group may also arise when the subsidiary is demanded, for example: to pay management fees or dividends to the parent; to employ particular individuals; to give up a new business to allow another member entity to launch it; or to provide financial assistance for a distressed member.

The risk of unfavourable intra-group transactions is a part of the broader problem of conflicts of interest between the controlling shareholder and the controlled company, which raises the issue of the protection of minority shareholders and other stakeholders. However, the problem may be more complicated in the case of intra-group transactions, as they may be carried out with a high frequency and a wide scope. For example, some groups operate a centralised cash management system in which cash surplus of member companies is collected daily at the centre function and then distributed to the companies in need of cash. Such an arrangement is disadvantageous for the former companies losing investment opportunities when obliged to give up cash, although it could turn out to be beneficial in other circumstances when they become short of cash. The more coordinated or centralised the management is of 
member companies in a group and therefore the more inter-dependent these companies are, the more often boards of subsidiaries may face such conflicts.

Various measures are taken to address the conflicts of interest in related party transactions, including intra-group transactions. Those cover: i) disclosure, ii) board approval, iii) shareholder approval, and iv) prohibition.

\section{Disclosure requirement}

First, mandatory disclosure is the most commonly used measure against abusive related party transactions. By putting targeted transactions under the eyes of various stakeholders as well as analysts and the media, disclosure can effectively curb abusive transactions with the threats of lowering share prices and damaging reputation, while permitting reasonable ones. Mandatory disclosure can also provide a useful ground for actions against corporate misconduct, as its failure is relatively easy to prove (Enriques et al 2009).

A number of jurisdictions around the world have adopted financial reporting standards, such as IAS 24 (Related Party Disclosure), which require disclosure of related party transactions annually in financial statements. Moreover, listed companies are obliged to reveal detailed information on related party transactions in the form of a corporate governance report, which is usually included in an annual report (OECD 2015a).

Although the financial reporting standards have brought a significant convergence in the disclosure of related party transactions worldwide particularly for listed companies, there remain differences among jurisdictions in what and when to disclose. For example, the EU Company Law Directives on corporate accounting $^{6}$ require the member states to oblige companies (except for smaller ones) to disclose all related party transactions if such transactions are material and have not been concluded under normal market conditions (OECD 2012). However, the interpretation of "material" or "normal market conditions" may differ among the states. As described above, the German group law stipulates that all the disadvantaging transactions induced by the parent need to be recorded and audited but not to be disclosed to minority shareholders. ${ }^{7}$ Moreover, while IAS 24 and the equivalent local standards require the annual disclosure in the financial statements, some jurisdictions obligate listed companies to conduct immediate disclosure by a circular if the transaction is significant. Nonetheless, the disclosure requirement does not necessarily cover non-listed companies.

The implementation of effective disclosure of related party transactions is supported by internal and/or external audit playing as the gatekeeper. In recent years, auditors are increasingly required to pay special attention to related party transactions by the International Standards on Auditing and national regulations.

\section{Board approval $^{8}$}

Second, the requirement of board approval can be used to protect minority shareholders and other stakeholders against abusive related party transactions. In principle, board directors have the duty of

Article 17(1)(r) and Article 2(16) in the Directive 2013/34/EU.

7 Enriques et al (2009) suggest that the lack of disclosure may be compensated by a broad-sweeping shareholder's right to ask questions, which may force managers to provide detailed information on the relationship between controlling and controlled companies.

8 This section and the following one draw substantially on OECD (2015a). 
loyalty to act in the interest of the company when handling related party transactions. However, it is not obvious in many jurisdictions that this legal duty works strictly in the context of intra-group transactions, as illustrated above.

Instead, many jurisdictions explicitly require board approval for some types of related party transactions, which still differ considerably among countries from all non-routine ones to only lending to board directors. In this context, independent directors play an important role based on the premise that they may bring an objective view. Moreover, some jurisdictions adopt a special board approval arrangement for certain related party transactions, which typically involves independent board members, auditors or outside specialists (such as independent appraisers in Indonesia) ${ }^{9}$.

\section{Shareholder approval}

Third, some jurisdictions require shareholder approval to screen potentially abusive related party transactions. As shareholder approval is a cumbersome and costly process, it is normally limited only to important transactions, such as large ones (relative to market capitalisation, for example) and/or the ones not on market terms or on a routine basis. In order to assist shareholder approval, some countries mandate that an opinion from auditors (e.g. France) or outside specialists (e.g. Indonesia) be provided.

Shareholder approval is justified in that it is ultimately (minority) shareholders that could suffer from the abusive transactions and therefore have a direct interest in the decision making. Accordingly, some jurisdictions require the "majority of minority shareholders" voting for shareholder approval ${ }^{10}$. Minority shareholder approval is recognised as the most reliable method of screening conflicted transactions with controlling shareholders in the judicial tradition of the United Kingdom and the United States (Enriques et al 2009).

\section{Prohibition of transactions}

The ultimate way to prevent abusive related party transactions is to prohibit such transactions. In fact, certain types of transactions are banned in some jurisdictions. For example, the officers, directors and controlling shareholders are not allowed to trade their company's securities before the disclosure of material information (ditto). However, seemingly no countries prohibit intra-group transactions, obviously because such transactions can be rational and beneficial to the company and its group, despite the risk of abuse involved.

\section{Financial regulation}

Intra-group transactions are a particular concern for financial regulation, as they could affect financial soundness of financial subsidiaries. For example, the Joint Forum Principles 2012 emphasise: Supervisors should require that the governance framework includes adequate policies and processes that enable

9 In Belgium, India, Italy and Singapore, the independent committee or audit committee must approve non-equity related party transactions (excluding remuneration). In Austria and Hungary, the supervisory board should do so. Review by independent board members is not legally required in the United States, but is effectively necessary as the courts put importance on it. Moreover, In Canada, a report by the auditor and a valuation by a qualified evaluator are both mandated. In France, the auditor needs to prepare a special report for shareholder authorisation. In Indonesia, an independent appraiser registered in OJK can even substitute board approval (OECD 2015a).

10 Such countries include typically the United Kingdom, but also Canada, France, Israel and Italy. Indonesia also mandates such voting for the approval of a certain type of transactions (i.e. those with conflicts of interest). In the United States, boards of directors are encouraged to seek the approval of a majority of minority shareholders in order to secure the support of the business judgement rule under state law jurisprudence (OECD, 2015a). 
potential intra-group conflicts of interest to be avoided, and actual conflicts of interest to be identified and managed (Implementation criteria 10(e)). When identifying inappropriate intra-group transactions involving financial subsidiaries, the financial supervisor may use its power to require corrective actions to the subsidiary and/or its parent.

The abusive transactions typically associated with financial subsidiaries take place when finance is provided for other entities in the group in too generous of terms. This type of problem should also be addressed as a risk management issue for the financial subsidiary. Many jurisdictions have prudential regulation to restrict credit exposure to single counterparties or groups of connected counterparties ${ }^{11}$. Such regulations seem to avoid excessive risk concentration in financial institutions, which could affect their financial soundness. When applied to financial subsidiaries, it may function as a prohibition of credit extension beyond thresholds for the parents and other member companies in the groups.

11 Refer to Principle 19: Concentration risk and large exposure limits of BCBS Core Principles for Effective Banking Supervision (BCBS 2012). 


\section{CROSS-BORDER IMPLICATIONS}

In many instances, financial groups' operations and structures are organised across borders. Doing business abroad is often the reason for forming a corporate group, typically when the local regulation requires establishing a corporation locally in order to do a financial business. Governance of the groups including member companies in different jurisdictions requires special considerations for the groups and also for the financial supervisors.

\section{Perspective of corporate groups}

For the corporate group perspective, the ultimate parent, responsible for the group-wide governance, should recognise different laws, regulations and rules in the jurisdictions where the subsidiaries are established. Mandatory rules and requirements must be obeyed in order to continue the business in the jurisdiction. The group policies need to be adjusted at the subsidiary level where they conflict with such local rules and requirements.

The subsidiary board and management are primarily responsible for compliance to the local rules and requirements. They are required to make necessary inputs to the parent so as to manage local compliance risks adequately. In this regard, the subsidiary board may benefit from involving one or more local individuals who have local knowledge and expertise. This is a legal requirement in some jurisdictions. Local compliance may also be ensured by making use of local practitioners outside of the board.

Where the local rules and customs are not mandatory and conflict with the group policies, careful consideration should be given. Obedience to these rules and customs may allow companies to avoid the risk of a local compliance problem, but could damage the integrity of the group. It is imperative that the parent board and senior management should understand clearly such situations with significant inputs from the subsidiary and make the strategic decisions so as to minimise the risk of undesired consequences.

\section{Perspective of financial supervisors}

For financial supervisors, cross-border operations of financial groups pose a serious challenge for their effective supervision, as they may not be able to verify the operations outside of their jurisdiction directly. This is especially true for host supervisors, because they cannot supervise the major part of the operations of the financial group directly and therefore have to rely on the foreign counterparts.

The information on the operations outside of the territory should be collected through the entities located domestically. Occasional communication with the headquarters of the financial groups is also necessary. Nonetheless, the close communication and coordination with the relevant foreign authorities is of utmost importance for effective supervision. 


\section{CONCLUSIONS}

Companies are increasingly operating in group structures worldwide. Corporate groups are formed for various business reasons. Particularly in the financial sector, regulation may encourage the formation of corporate groups by requiring separately capitalised entities for certain businesses.

Corporate groups, including financial groups, differ considerably in their size, structure, business, relationship between members, and so on. Accordingly, effective governance may necessarily take different shapes. There are no "one size fits all" solutions.

Nevertheless, generally speaking, corporate groups may need to be governed and managed in a holistic and integrated manner so as to maximise the benefits and minimise the risks of doing business in a group. The boards and senior executives of the ultimate parent should be responsible for setting groupwide strategy and monitoring management and governance group-wide, as those of a company are with regard to the company. In this context, the relevant considerations for good governance of corporate groups may not be different from those of large stand-alone corporations with numerous divisions and branches. Various recommendations for good corporate governance should largely be applicable to corporate groups.

It should also be noted, however, that the governance of corporate groups deserves additional attention. First, the complexity in group structures with a multi-layered ownership across borders may pose a challenge for the governance of corporate groups. At a group level, the board and senior management of the ultimate parent should understand clearly the structure of the group and member companies, establish the group-wide strategy and set effective group-wide governance policies and arrangements. The framework for reviewing and disclosing related party transactions within a complicated nexus of member companies should also be carefully addressed and clearly set out.

Second, it should be recognised that, unlike company branches, subsidiary companies are separate legal entities and have their own governance constituencies. The governance of corporate groups should inherently deal with the dilemma for subsidiary board directors when the interest of the parent or the group comes into conflict with that of the company, for which they have a fiduciary duty. Especially when a subsidiary has minority shareholders, the governance at a group level should provide a means to ensure consideration of their interests, for example in setting subsidiary-level strategies. At a subsidiary level, the boards should be properly composed according to their clearly defined roles and responsibilities.

For financial groups, the importance and challenges related to their governance are highlighted by financial regulation and supervision. While emphasising the overall responsibility of the ultimate parents of financial groups, financial regulation normally requires the boards of financial subsidiaries to retain their governance and management responsibilities. After the recent global financial crisis, financial regulation seems to put increasing stress on the independence in governance of financial subsidiaries within groups, which may intensify tension with financial groups that seek more integrated management. Due to financial regulation and supervision, the governance of financial groups, both at group and subsidiary levels, is required to take into account the interests of unsecured creditors, such as depositors and insurance policyholders of the financial subsidiaries. 


\section{REFERENCES}

Andenas, Mads and Frank Wooldridge (2009), Groups of companies, European Comparative Company Law, Cambridge University Press

BCBS (2012), Core Principles for Effective Banking Supervision, Basel Committee on Banking Supervision, September 2012

BCBS (2015), Corporate governance principles for banks, Basel Committee on Banking Supervision, July 2015

Conac, Pierre-Henri, Lucas Enriques and Martin Gelter (2007), "Constraining Dominant Shareholders' Self Dealing: The Legal Framework in France, Germany and Italy”, ECGI Working Paper Series in Law, Working Paper No. 88/2007

Conac, Pierre-Henri (2013), "Director's Duties in Groups of Companies - Legalizing the Interest of the Group at the European Level", European Company and Financial Law Review (ECFR) 2013, pp194-226

Enriques, Luca, Gerard Hertig and Hideki Kanda (2009), "Related-Party Transactions", The anatomy of Corporate Law - A Comparative and Functional Approach, Second Edition, Oxford University Press, 2009

EMCA (2013), European Model Company Act Draft 2015, European Model Company Act Group, July 2015

FSB (2009), FSB Principles for Sound Compensation Practices - Implementation Standards, September 2009

Frederick, W. Richard (2014), "Challenges in Group Governance: The Governance of Cross-Border Bank Subsidiaries”, IFC Corporate Governance Knowledge Publication, 2014

Hausmann, Yannick and Elisabeth Bechtold (2015), "Corporate Governance of Groups in an Era of Regulatory Nationalism - An Analysis with a Focus of Financial Services Regulation", ECFR $3 / 2015$

Hopt, Klaus J. (2015), "Groups of Companies - A Comparative Study on the Economics, Law and Regulation of Corporate Groups", ECGI Working Paper Series in Law No. 286/2015

ILA (2015), Group interest and subsidiary governance in Luxembourg, Institut Luxembourgeois des Administrateurs, June 2015

IAIS (2014), Issues Paper on Approaches to Group Corporate Governance, International Association of Insurance Supervisors, October 2014, available at http://www.iaisweb.org/page/supervisorymaterial/issues-papers//file/34545/issues-paper-on-approaches-to-group-corporate-governance 
IAIS (2015), Insurance Core Principles, Updated in November 2015, IAIS, available at www.iaisweb.org/page/supervisory-material/insurance-core-principles

Joint Forum (2012), Principles for the supervision of financial conglomerates, September 2012

Lumpkin, Stephen (2011), "Risks in Financial Group Structure", OECD Journal: Financial Market Trends, Vol. 2010/2, DOI: http://dx.doi.org/10.1787/fmt-2010-5kggc0z2f0g0

Mak, Yuen Teen and Chris Bennett (2014), Governance of Company Groups, CPA Australia, July 2014

Mehran, Hamid, Alan Morrison and Joel Shapiro (2011), "Corporate Governance and Banks: What Have We Learned from the Financial Crisis?”, Federal Reserve Bank of New York Staff Reports, no. 502

Mescher, Barbara and Brett Bondfield (2013), "Corporate Groups and the Duty of Directors - To Act in Their Company's Best Interests”, University of Sydney Business School, the Journal of Applied Research in Accounting and Finance (JARAF) 2013 Vol. 8 Issue 2

OECD (2011), OECD Guidelines on Insurer Governance, OECD Publishing, Paris. DOI: http://dx.doi.org/10.1787/9789264129320-en

OECD (2012), Related Party Transactions and Minority Shareholder Right, OECD Publishing, Paris. DOI: http://dx.doi.org/10.1787/9789264168008-en

OECD (2015a), Corporate Governance Factbook, March 2015, available at www.oecd.org/daf/ca/corporate-governance-factbook.htm

OECD (2015b), G20/OECD Principles of Corporate Governance, OECD Publishing, Paris. DOI: http://dx.doi.org/10.1787/9789264236882-en

OECD (2015c), Corporate Governance of Company Groups in Latin America, OECD Publishing, Paris. DOI: http://dx.doi.org/10.1787/9789264241725-en

Troeger, Tobias H. (2014), “Corporate Groups”, SAFE Working Paper No. 66 


\section{Corporate Governance Principles for Banks, Basel Committee on Banking Supervision, July 2015 (extract)}

\section{Principle 5: Governance of group structures}

In a group structure, the board of the parent company has the overall responsibility for the group and for ensuring the establishment and operation of a clear governance framework appropriate to the structure, business and risks of the group and its entities. ${ }^{21}$ The board and senior management should know and understand the bank group's organisational structure and the risks that it poses.

\section{Parent company boards}

95. In operating within a group structure, the board of the parent company should be aware of the material risks and issues that might affect both the bank as a whole and its subsidiaries. It should exercise adequate oversight over subsidiaries while respecting the independent legal and governance responsibilities that might apply to subsidiary boards.

96. In order to fulfil its responsibilities, the board of the parent company should:

- establish a group structure (including the legal entity and business structure) and a corporate governance framework with clearly defined roles and responsibilities, including those at the parent company level and at the subsidiary level as may be appropriate based on the complexity and significance of the subsidiary;

- define an appropriate subsidiary board and management structure which takes into account the material risks to which the group, its businesses and its subsidiaries are exposed;

- assess whether the group's corporate governance framework includes adequate policies, processes and controls and whether the framework addresses risk management across the businesses and legal entity structures;

- ensure that the group's corporate governance framework includes appropriate processes and controls to identify and address potential intragroup conflicts of interest, such as those arising from intragroup transactions;

- approve policies and clear strategies for establishing new structures and legal entities, and ensure that they are consistent with the policies and interests of the group;

- assess whether there are effective systems in place to facilitate the exchange of information among the various entities, to manage the risks of the separate subsidiaries or group entities as well as of the group as a whole, and to ensure effective supervision of the group;

- have sufficient resources to monitor the compliance of subsidiaries with all applicable legal, regulatory and governance requirements;

21 Banks that are part of a conglomerate should also take into account the Joint Forum's Principles for the supervision of financial conglomerates (September 2013, available at www.bis.org/publ/joint29.htm). For the purposes of the corporate governance principles herein, the terms "parent company" and "group" signify a financial group. 
- maintain an effective relationship with both the home regulator and, through the subsidiary board or direct contact, with the regulators of all subsidiaries;

- establish an effective internal audit function that ensures audits are being performed within or for all subsidiaries and part of the group and group itself; ${ }^{22}$ and

- ensure that the group's corporate governance framework includes appropriate processes and controls to identify and address potential intragroup conflicts of interest, such as those arising from intragroup transactions, in appropriate recognition of the interest of the group.

\section{Subsidiary boards $\mathbf{s}^{23}$}

97. Subsidiary boards and senior management remain responsible for developing effective risk management processes for their entities. The methods and procedures applied by subsidiaries should support the effectiveness of risk management at a group level. While parent companies should conduct strategic, group-wide risk management and prescribe corporate risk policies, subsidiary management and boards should have appropriate input to their local or regional application and to the assessment of local risks. Parent companies should ensure that adequate tools and authorities are available to the subsidiary and that the subsidiary understands the reporting obligations it has to the head office. It is the responsibility of subsidiary boards to assess the compatibility of group policy with local legal and regulatory requirements and, where appropriate, amend those policies.

98. While the strategic objectives, risk governance framework, corporate values and corporate governance principles of the subsidiary should align with that of the parent company (referred to here as "group policies"), the subsidiary board should make necessary adjustments where a group policy conflicts with an applicable legal or regulatory provision or prudential rule, or would be detrimental to the sound and prudent management of the subsidiary.

99. In the case of a significant regulated subsidiary (due to its risk profile or systemic importance or due to its size relative to the parent company), the board of the significant subsidiary should take such further steps as are necessary to help the subsidiary meet its own corporate governance responsibilities and the legal and regulatory requirements that apply to it.

\section{Complex or opaque structures}

100. Banks create structures for legal, regulatory and tax purposes. Structures can take the form of units, branches, subsidiaries or other legal entities that can considerably increase the complexity of the organisation. The number of legal entities, and in particular the interconnections and intragroup transactions among such entities, can lead to challenges in identifying and managing the risks of the organisation as a whole.

101. Operating through complex or non-transparent structures may pose financial, legal, reputational and other risks to the bank. It may impede the ability of the board and senior management to conduct appropriate business oversight and could hinder effective banking supervision. ${ }^{24}$

\footnotetext{
22 See the Committee's Internal audit function in banks at www.bis.org/publ/bcbs223.pdf.

23 See also paragraph 123 in Corporate Governance Principles for Banks.

24 In addition, the bank may also be indirectly exposed to risk when it performs certain services or establishes structures on behalf of customers. See BCBS, Customer due diligence for banks, October 2001, available at www.bis.org/publ/bcbs $85 . h t m$. Examples include acting as a company or partnership formation agent, providing a range of trustee services and developing complex structured finance transactions for customers. While these activities are often profitable and can serve the legitimate business purposes of customers, customers may in some cases use products and activities provided by banks to engage in illegal or inappropriate activities.
} 
102. Senior management - and the board, as appropriate - should be cognisant of these challenges and take action to avoid or mitigate them by:

- avoiding setting up complicated structures that lack economic substance or business purpose;

- continually maintaining and reviewing appropriate policies, procedures and processes governing the approval and maintenance of those structures or activities, including fully vetting the purpose, the associated risks and the bank's ability to manage those risks prior to setting up new structures and initiating associated activities;

- having a centralised process for approving the creation of new legal entities and subsidiaries based on established criteria, including the ability to monitor and fulfil each entity's regulatory, tax, financial reporting, governance and other requirements and for the dissolution of dormant subsidiaries;

- establishing adequate procedures and processes to identify and manage all material risks arising from these structures, including lack of management transparency, operational risks introduced by interconnected and complex funding structures, intragroup exposures, trapped collateral and counterparty risk. The bank should only approve structures if the material risks can be properly identified, assessed and managed; and

- ensuring that the activities and structure are subject to regular internal and external audit reviews.

103. The board of the parent company can enhance the effectiveness of the above efforts by requiring a periodic independent formal review of the structures, their controls and activities as well as of their consistency with board-approved strategy.

104. The board should be prepared to discuss with, and as necessary report to, the bank's supervisor and the host country supervisors the policies and strategies adopted regarding the establishment and maintenance of these structures and activities. 
Appendix $B$

Principles for the Supervision of Financial Conglomerates, Joint Forum, September 2012 (extract)

\section{Corporate Governance}

Broadly, corporate governance describes the processes, policies and laws that govern how a company or group is directed, administered or controlled. It defines the set of relationships between a company's management, its board, its shareholders, and other recognised stakeholders. ${ }^{14}$ Corporate governance also provides the structure through which the objectives of the company are set, and the means of attaining those objectives and monitoring performance are determined.

Good corporate governance should provide proper incentives for the board and management to pursue objectives that are in the interests of the company and its shareholders and should facilitate effective monitoring. The presence of an effective corporate governance system, within an individual company or group and across an economy as a whole, helps to provide a degree of confidence that is necessary for the proper functioning of a market economy.

Financial conglomerates are often complex groups with multiple regulated and unregulated financial and other entities. Given this inherent complexity, corporate governance must carefully consider and balance the combination of interests of recognised stakeholders of the ultimate parent, and the regulated financial and other entities of the group. Ensuring that a common strategy supports the desired balance and that regulated entities are compliant with regulation on an individual and on an aggregate basis should be a goal of the governance system. This governance system is the fiduciary responsibility of the board of directors.

When assessing corporate governance across a financial conglomerate, supervisors should apply these principles in a manner that is appropriate to the relevant sectors and the supervisory objectives of those sectors.

This section describes the elements of the governance system most relevant to financial conglomerates, and how they should be assessed by supervisors.

\section{Corporate governance in financial conglomerates}

10. Supervisors should seek to ensure that the financial conglomerate establishes a comprehensive and consistent governance framework across the group that addresses the sound governance of the financial conglomerate, including unregulated entities, without prejudice to the governance of individual entities in the group.

\section{Implementation criteria}

10(a) Supervisors should require that the corporate governance framework of the financial conglomerate has minimum requirements for good governance of the entities of the financial conglomerate which allow for the prudential and legal obligations of its constituent entities to be effectively met.

14 The legal and regulatory system in a country determines the formal responsibilities institutions have to shareholders and other relevant stakeholders. This document will use the phrase "recognised stakeholders" to reflect the fact that responsibilities in this regard vary across jurisdictions and sectors. 
The ultimate responsibility for the sound and prudent management of a financial conglomerate rests with the board of the head of the financial conglomerate.

10(b) Supervisors should require that the financial conglomerate emphasises a high degree of integrity in the conduct of its affairs.

10(c) Supervisors should seek to ensure that the corporate governance framework appropriately balances the diverging interests of constituent entities and the financial conglomerate as a whole.

10(d) Supervisors should require that the governance framework respects the interests of policy holders and depositors (where relevant), and should seek to ensure that it respects the interests of other recognised stakeholders of the financial conglomerate and the financial soundness of entities in the financial conglomerate.

10(e) Supervisors should require that the governance framework includes adequate policies and processes that enable potential intra-group conflicts of interest to be avoided, and actual conflicts of interest to be identified and managed.

\section{Explanatory comments}

10.1 The corporate governance framework should address where appropriate:

- alignment to the structure of the financial conglomerate;

- financial soundness of the significant owners;

- suitability of board members, senior management and key persons in control functions including their ability to make reasonable and impartial business judgments;

- fiduciary responsibilities of the boards of directors and senior management of the head company and material subsidiaries;

- management of conflicts of interest, in particular at the intra-group level and remuneration policies and practices within the financial conglomerate; and

- internal control and risk management systems and internal audit and compliance functions for the financial conglomerate.

10.2 The group's corporate governance framework should notably include a strong risk management framework (refer to the Risk Management section), a robust internal control system, effective internal audit and compliance functions, and ensure that the group conducts its affairs with appropriate independence and a high degree of integrity.

10.3 Group-wide governance not only involves the governance of the head of the financial conglomerate, but also applies group-wide to all material activities and entities of the financial conglomerate.

10.4 In the event the local corporate governance requirements applicable to any particular material entity in the financial conglomerate are below the group standards, the more stringent group corporate governance standards should apply, except where this would lead to a violation of local law.

10.5 Supervisors should require that the corporate governance framework of the financial conglomerate includes a code of ethical conduct.

10.6 Supervisors should require that the financial conglomerate have in place policies focused on identifying and managing potential intra-group conflicts of interest, including those that may result from intra-group transactions, charges, up streaming dividends, and risk-shifting. The policies should be approved by the board of the head of the financial conglomerate and be effectively implemented throughout the group. The policies should recognise the long-term interest of the financial conglomerate as a whole, the long term interest of the significant entities of the financial 
conglomerate, the stakeholders within the financial conglomerate, and all applicable laws and regulations.

\section{Structure of the financial conglomerate}

11. Supervisors should seek to ensure that the financial conglomerate has a transparent organisational and managerial structure, which is consistent with its overall strategy and risk profile and is well understood by the board and senior management of the head company.

\section{Implementation criteria}

11(a) Supervisors should understand the financial conglomerate's group structure and the impact of any proposed changes to this structure.

11(b) Supervisors should assess the ownership structure of the financial conglomerate, including the financial soundness and integrity of its significant owners.

11(c) Supervisors should seek to ensure that the structure of the financial conglomerate does not impede effective supervision. Supervisors may seek restructuring under appropriate circumstances to achieve this, if necessary.

11(d) Supervisors should seek to ensure that the board and senior management of the head of the financial conglomerate are capable of describing and understanding the purpose, structure, strategy, material operations, and material risks of the financial conglomerate, including those of unregulated entities that are part of the financial conglomerate structure.

11(e) Supervisors should assess and monitor the financial conglomerate's process for approving and controlling structural changes, including the creation of new legal entities.

11(f) Where the financial conglomerate is part of a wider group, supervisors should require that the board and senior management of the head of the financial conglomerate have governance arrangements that enable material risks stemming from the wider group structure to be identified and appropriately assessed by relevant supervisory authorities.

11(g) Supervisors should seek to ensure that there is a framework governing information flows within the financial conglomerate and between the financial conglomerate and entities of the wider group (eg reporting procedures).

\section{Explanatory comments}

11.1 A financial conglomerate may freely set its functional, hierarchical, business and/or regional organisation, provided all entities within the financial conglomerate comply with their relevant sectoral and legal frameworks.

11.2 Elements to be considered for assessing the significant ownership structure of the financial conglomerate may include the identification of significant owners, including the ultimate beneficial owners, the transparency of their ownership structure, their financial information, and the sources of their initial capital and all other requirements of national authorities. At a minimum, the necessary qualities of significant owners relate to the integrity demonstrated in personal behaviour and business conduct, as well as to the ability to provide additional support when needed.

11.3 Supervisors should seek to ensure that a financial conglomerate has an organisational and managerial structure that promotes and enables prudent management, and if necessary, orderly resolution aligned with corresponding sectoral requirements. Reporting lines within the financial 
conglomerate should be clear and should facilitate information flows within the financial conglomerate, both bottom-up and top-down.

11.4 Supervisors should be satisfied that the board and senior management of the head of the financial conglomerate understand and influence the evolution of an appropriate group legal structure in alignment with the approved business strategy and risk profile of the financial conglomerate, and understand how the various elements of the structure relate to one another. Where a financial conglomerate creates many legal entities, their number and, particularly, the interconnections and transactions between them, may pose challenges for the design of effective corporate governance arrangements. This risk should be recognised and managed. This is particularly the case where the organisational and managerial structure of the financial conglomerate deviates from the legal entity structure of the financial conglomerate.

11.5 Supervisors should assess changes to the group structure and how these changes impact its soundness, especially where such changes cause the financial conglomerate to engage in activities and/or operate in jurisdictions that impede transparency or do not meet international standards stemming from sectoral regulation.

\section{Suitability of board members, senior managers and key persons in control functions}

12. Supervisors should seek to ensure that the board members, senior managers and key persons in control functions in the various entities in a financial conglomerate possess integrity, competence, experience and qualifications to fulfil their role and exercise sound objective judgment.

\section{Implementation criteria}

12(a) Supervisors should be satisfied of the suitability of board members, senior managers and key persons in control functions.

12(b) Supervisors should require financial conglomerates to have satisfactory processes for periodically assessing suitability.

12(c) Supervisors should require that the members of the boards of the head of the financial conglomerate and of its significant subsidiaries act independently of parties and interests external to the wider group; and that the board of the head of the financial conglomerate include a number of members acting independently of the wider group (including owners, board members, executives, and staff of the wider group).

12(d) Supervisors should communicate with the supervisors of other regulated entities within the conglomerate when board members, senior management and key persons in control functions are deemed not to meet their suitability tests.

\section{Explanatory comments}

12.1 Board members, senior managers and key persons in control functions need to have appropriate skills, experience and knowledge, and act with care, honesty and integrity, in order to make reasonable and impartial business judgments and strengthen the protection afforded to recognised stakeholders. To this end, institutions need to prudently manage the risk that persons in positions of responsibility may not be suitable. Suitability criteria may vary depending on the degree of influence on or the responsibilities for the financial conglomerate.

12.2 Supervisors of regulated entities of the financial conglomerate are subject to statutory and other requirements in applying suitability tests to these entities in their jurisdiction. The organisational 
and managerial structure of financial conglomerates adds elements of complexity for supervisors seeking to ensure the suitability of persons. For instance, the management of regulated entities within the financial conglomerate can be extensively influenced by persons who are not directly responsible for such functions. A group-wide perspective regarding suitability of persons is intended to close any loopholes in this respect. Supervisors may rely on assessments made by other relevant supervisors in this area regarding suitability. Alternatively they may decide on concerted supervisory actions regarding suitability if required.

12.3 In order to meet suitability requirements, board members, senior managers and key persons in control functions, both individually and collectively, should have and demonstrate the ability to perform the duties or to carry out the responsibilities required in their position. Competence can generally be judged from the level of professionalism (eg pertinent experience within financial industries or other businesses) and/or formal qualifications.

12.4 Serving as a board member or senior manager of a company (from the wider group) that competes or does business with the regulated entities in the financial conglomerate can compromise independent judgment and create conflicts of interest, as can cross-membership on boards. A board's ability to exercise objective judgment independent of the views of executives and of inappropriate political or personal interests can be enhanced by recruiting members from a sufficiently broad population of candidates. The key characteristic of independence is the ability to exercise objective, independent judgment after fair consideration of all relevant information and views without undue influence from executives or from inappropriate external parties and interests and while taking into account the requirements of applicable law.

\section{Responsibility of the board of the head of the financial conglomerate}

13. Supervisors should require that the board of the head of the financial conglomerate appropriately defines the strategy and risk appetite of the financial conglomerate, and ensures this strategy is implemented and executed in the various entities, both regulated and unregulated.

\section{Implementation criteria}

13(a) Supervisors should require that the board of the head of the financial conglomerate has in place a framework for monitoring compliance with the strategy and risk appetite across the financial conglomerate.

13(b) Supervisors should require that the board of the head of the financial conglomerate regularly assesses the strategy and risk appetite of the financial conglomerate to ensure it remains appropriate as the conglomerate evolved.

13(c) Where the financial conglomerate is part of a wider group, supervisors should assess whether the head is managing its relationship with the wider group and ultimate parent in a manner that is consistent with the governance framework of the financial conglomerate.

13(d) Supervisors should require that a framework is in place which seeks to ensure resources are available across the financial conglomerate for constituent entities to meet both the group and their own entity's governance standards. 


\section{Explanatory comments}

13.1 Supervisors should assess if the board of directors exercises adequate oversight over the management of the head of the financial conglomerate. This includes assessing the actions taken by the board of the head to define the strategy for the financial conglomerate and ensure the consistency of the operations of the various entities in the financial conglomerate with such strategy. To this end, the head company should set up an adequate corporate governance framework in line with the structure, business and risks of the financial conglomerate and its entities and applicable laws. This framework should ensure that the strategy is implemented and monitored throughout the financial conglomerate and reviewed on a regular basis and following material change including due to growth, increased complexity, geographic expansion, etc.

13.2 The head company should exercise adequate oversight of subsidiaries, both regulated and unregulated, while respecting independent legal and governance responsibilities. Supervisors should satisfy themselves that entities within a financial conglomerate adhere to the same groupwide corporate governance principles or at least apply policies that remain consistent with these principles. The board of a regulated subsidiary of a financial conglomerate will retain and set its own corporate governance responsibilities and practices in line with its own legal requirements or in proportion to its size or business. These should not, however, conflict with the broader financial conglomerate corporate governance framework. Appropriate governance arrangements will address arrangements such that legal or regulatory provisions or prudential rules of regulated subsidiaries will be known and taken into account by the head company.

13.3 Where the financial conglomerate is part of a wider group structure, the head of the financial conglomerate is responsible for managing the relationship with its wider group. This includes ensuring there are appropriate arrangements for capital and liquidity management, assessing any material risk impact that may come from decisions made at its ownership level, service level agreements, reporting lines and regular top-level consultations with related companies in the wider group and the ultimate parent.

13.4 For smaller institutions within a larger conglomerate, it may be unnecessary to duplicate systems and controls. Such smaller institutions can rely on the systems and controls of the head if they have assessed that this is suitable to address group risks.

13.5 Supervisors should be satisfied with the amount and quality of information they receive from the head company of the financial conglomerate on its strategy, risk appetite and corporate governance framework.

\section{Remuneration in a financial conglomerate}

14. Supervisors should require that the financial conglomerate has and implements an appropriate remuneration policy that is consistent with its risk profile. The policy should take into account the material risks that organisation is exposed to, including those from its employees' activities.

\section{Implementation criteria}

14(a) Supervisors should require that an appropriate remuneration policy consistent with established international standards is in place and observed at all levels and across jurisdictions in the financial conglomerate. An appropriate policy aligns risk-takers' variable remuneration with prudent risk taking, promotes sound and effective risk management, and takes into account any other appropriate factors. The overarching objective of the policy should be consistent across the group 
but can allow for reasonable differences based on the nature of the constituent entities/units and local legal requirements.

14 (b) Supervisors should require that ultimate oversight of the remuneration policy rest with the financial conglomerate's head company.

14(c) Supervisors should require that the remuneration of board members, senior managers and key persons in control functions be determined in a manner that does not incentivise them to disregard the obligations they owe to the financial conglomerate or any of its entities, nor to otherwise act in a manner contrary to any legal or regulatory obligations.

14(d) Supervisors should require that the risks associated with remuneration are reflected in the financial conglomerate's broader risk management framework. For example, staff engaged in financial and risk control at the group-wide level should be compensated in a manner that is consistent with their control role and should be involved in designing incentive arrangements, and assessing whether such arrangements encourage imprudent risk-taking.

14(e) Supervisors should require that the variable remuneration received by risk management and control personnel is not based substantially on the financial performance of the business units that they review but rather on the achievement of the objectives of their functions (eg adherence to internal controls).

\section{Explanatory comments}

14.1 Remuneration is a key aspect of any governance framework and needs to be properly considered in order to mitigate the risks that may arise from poorly designed remuneration arrangements. The risks associated with remuneration should be reflected in the financial conglomerate's broader risk management framework.

14.2 Remuneration may serve important objectives, including attracting skilled staff, promoting better organisation-wide and employee performance, promoting retention, providing retirement security and allowing personnel costs to vary with revenues. It is also clear, however, that ill-designed compensation arrangements can provide incentives to take risks that are not consistent with the long term health of the organisation. Such risks and misaligned incentives are of particular supervisory interest.

14.3 Ultimately a financial conglomerate's remuneration policy should aim to ensure effective governance of remuneration, alignment of remuneration with prudent risk-taking, and engagement of recognised stakeholders.

14.4 Supervisors should ensure that the governance system identifies and closes loopholes that allow the circumvention of conglomerate, sectoral or entity-level remuneration requirements.

14.5 Board members, senior managers and key persons in control functions should be measured against performance criteria tied not only to the short-term, but also to the long-term interest of the financial conglomerate as a whole. 
Appendix C

OECD Guidelines on Insurer Governance, 2011 (extract)

\section{GROUPS AND CONGLOMERATES}

\section{A. Transparency and knowledge of structure}

- Group or conglomerate (hereafter "group") ownership, structures, arrangements and relations should be transparent to all entities within the group and related shareholders as well as to external stakeholders, and should be well understood by boards of directors and key executives.

The purpose, function and activities of all the major entities within a group, and the jurisdiction out of which they operate, should be disclosed.

\section{B. Comprehensive view}

- The boards and key executives of controlling and controlled entities within a group should have a comprehensive view of the business, operations and overall risks of the group and of the major entities within it.

- The boards and key executives of controlling and controlled entities within a group should have an understanding of any contagion risks within the group so that appropriate mitigation measures can be adopted.

\section{Governance system}

- A coherent, well-functioning and transparent governance system should be established within the group to ensure sound governance practices, with clear lines of responsibility and accountability across the group consistent with applicable legal requirements.

- This governance system should recognise the responsibility of the board of any insurer within a group to exercise independent decision-making and ensure the soundness and performance of the insurer.

- The control functions of the controlling entity in the group should appropriately consider a group-wide perspective in their activities and support, as appropriate and as may be requested, the control functions within controlled entities.

- The essential components of the control functions of an insurer within a group should be retained, permitting independent oversight of the insurer's operations and the identification and mitigation of contagion risks.

\section{Communication}

- There should be adequate group-wide flows of information to ensure that transparency and a comprehensive view can be brought to group arrangements, operations and risks, and that the risks related to group structures can be identified and mitigated. 
Insurance Core Principles, International Association of Insurance Supervisors, Updated November 2015 (extract)

\section{ICP 7 Corporate Governance}

The supervisor requires insurers to establish and implement a corporate governance framework which provides for sound and prudent management and oversight of the insurer's business and adequately recognises and protects the interests of policyholders.

\section{Insurance Groups}

7.0.7 Insurance groups should ensure that the corporate governance framework is appropriate to the structure, business and risks of the insurance group and its legal entities. The corporate governance framework should include policies, processes and controls which address risks across the insurance group and legal entities.

7.0.8 When setting up or evaluating their corporate governance framework, insurance groups should be aware of the specific challenges which might arise from the organisational model adopted by a group (e.g. centralised or decentralised model). The main factors underlying the challenges are:

- $\quad$ the division of authorities and responsibilities between the key players at the insurance group and legal entity level;

- $\quad$ effective group-wide direction and coordination;

- $\quad$ proper consideration of the legal obligations, governance responsibilities and risks both at the insurance group and legal entity level; and

- $\quad$ effective communication within the group and adequate information at all levels.

7.0.9 The supervisor should take the organisational structure of the group into consideration in evaluating its governance. Particularly when the management structure differs from the legal entity structure, it is not sufficient to assess governance only at the legal entity level. In such a case, it is important that appropriate governance exists across the group and that the supervisor assesses it on a group-wide basis.

\section{ICP 8 Risk Management and Internal Controls}

The supervisor requires an insurer to have, as part of its overall corporate governance framework, effective systems of risk management and internal controls, including effective functions for risk management, compliance, actuarial matters and internal audit.

\section{Special considerations for groups}

8.0.6 Group wide risks may affect insurance legal entities within a group, while risks at the insurance legal entity level could also affect the group as a whole. To help address this, groups should have strong risk management and compliance culture across the group and at the insurance legal entity 
level. Thus, in addition to meeting group governance requirements, the group should take into account the obligations of its insurance legal entities to comply with local laws and regulations.

8.0.7 How a group's systems of risk management and internal controls are organised and operate will depend on the governance approach the group takes, i.e., a more centralised or a more decentralised approach (see IAIS Issues Paper on Approaches to Group Corporate Governance; impact on control functions, October 2014). Regardless of the governance approach, it is important that effective systems of risk management and internal controls exist and that risks are properly monitored and managed at the insurance legal entity level and on a group-wide basis.

8.0.8 Additionally, a group's governance approach will also affect the way in which its control functions are organised and operated. Coordination between the insurance legal entity and group control functions is important to help ensure overall effective systems of risk management and internal controls. Regardless of how the group control functions are organised and operated, the result should provide an overall view of the group-wide risks and how they should be managed.

8.0.9 Supervisors should require the establishment of comprehensive and consistent group governance and assess its effectiveness. While the group-wide supervisor is responsible for assessing the effectiveness of the group's systems of risk management and internal controls, the other involved supervisors undertake such assessments on a legal entity basis. Appropriate supervisory cooperation and coordination is necessary to have a group-wide view and to enhance the assessment of the legal entities. 


\title{
OECD Corporate Governance Working Papers
}

\author{
www.oecd.org/daf/ca/oecdcorporategovernanceworkingpapers.htm
}

\begin{tabular}{|c|c|c|}
\hline $\mathrm{N}^{\mathrm{o}} 19$ & 6 April 2016 & $\begin{array}{l}\text { Concerns Related to the Internationalisation of State-Owned Enterprises } \\
\text { Sara Sultan Balbuena }\end{array}$ \\
\hline $\mathrm{N}^{\mathrm{o}} 18$ & 1 Sep 2015 & $\begin{array}{l}\text { Stocktaking of Anti-Corruption and Business Integrity Measures for Southern } \\
\underline{\text { African SOEs }} \\
\text { Mary Crane-Charef }\end{array}$ \\
\hline $\mathrm{N}^{\mathrm{o}} 17$ & 7 Aug 2015 & $\begin{array}{l}\text { How is corporate governance in Japan changing: Developments in listed companies } \\
\text { and roles of institutional investors } \\
\text { Ryoko Ueda }\end{array}$ \\
\hline $\mathrm{N}^{\mathrm{o}} 16$ & 12 Feb 2015 & $\begin{array}{l}\text { Corporate Bonds, Bondholders and Corporate Governance } \\
\text { Serdar Çelik, Gül Demirtaş and Mats Isaksson }\end{array}$ \\
\hline $\mathrm{N}^{\mathrm{o}} 15$ & 30 Sep 2014 & $\begin{array}{l}\text { Corporate Governance Enforcement in the Middle East and North Africa: Evidence } \\
\frac{\text { and Priorities }}{\text { Alissa Amico }}\end{array}$ \\
\hline $\mathrm{N}^{\mathrm{o}} 14$ & $23 \mathrm{Jul} 2014$ & $\begin{array}{l}\text { State-Invested Enterprises in the Global Marketplace: Implications for a Level } \\
\text { Playing Field } \\
\text { Hans Christiansen, Yunhee Kim }\end{array}$ \\
\hline $\mathrm{N}^{\mathrm{o}} 13$ & 15 Jan 2014 & $\begin{array}{l}\text { State-Owned Enterprise Governance: A Stocktaking of Reforms and Challenges in } \\
\text { Southern Africa } \\
\text { Sara Sultan Balbuena }\end{array}$ \\
\hline $\mathrm{N}^{\mathrm{o}} 12$ & 3 Dec 2013 & $\begin{array}{l}\text { Colombian SOEs: A Review Against the OECD Guidelines on Corporate } \\
\text { Governance of State-Owned Enterprises } \\
\text { Héctor Lehuedé }\end{array}$ \\
\hline $\mathrm{N}^{\mathrm{o}} 11$ & 3 Dec 2013 & $\begin{array}{l}\text { Institutional Investors as Owners: Who are they and what do they do? } \\
\text { Serdar Çelik, Mats Isaksson }\end{array}$ \\
\hline $\mathrm{N}^{\mathrm{o}} 10$ & $11 \mathrm{Jul} 2013$ & $\frac{\text { Making Stock Markets Work to Support Economic Growth }}{\text { David Weild, Edward Kim, Lisa Newport }}$ \\
\hline $\mathrm{N}^{\mathrm{o}} 9$ & 11 Jul 2013 & $\begin{array}{l}\text { Disclosure of Beneficial Ownership and Control in Indonesia } \\
\text { Fianna Jurdant }\end{array}$ \\
\hline $\mathrm{N}^{\mathrm{o}} 8$ & 19 Apr 2013 & $\begin{array}{l}\text { Who Cares? Corporate Governance in Today's Equity Markets } \\
\text { Mats Isaksson, Serdar Çelik }\end{array}$ \\
\hline $\mathrm{N}^{\circ} 7$ & 18 Jan 2013 & $\begin{array}{l}\text { Beneficial Ownership and Control: A Comparative Study - Disclosure, Information } \\
\text { and Enforcement } \\
\text { Erik P.M. Vermeulen }\end{array}$ \\
\hline $\mathrm{N}^{\circ} 6$ & 18 Jan 2013 & $\begin{array}{l}\text { Balancing Commercial and Non-Commercial Priorities of State-Owned Enterprises } \\
\text { Hans Christiansen }\end{array}$ \\
\hline
\end{tabular}



$\mathrm{N}^{\circ} 5 \quad 1$ Aug $2011 \quad \frac{\text { The Size and Composition of the SOE Sector in OECD Countries }}{\text { Hans Christiansen }}$

Competitive Neutrality and State-Owned Enterprises in Australia: Review of

$\mathrm{N}^{\circ} 4 \quad 1$ Aug $2011 \quad$ Practices and their Relevance for Other Countries

Matthew Rennie, Fiona Lindsay

N³ 1 Aug $2011 \quad$ The Exercise of Shareholder Rights: Country Comparison of Turnout and Dissent Paul Hewitt

№ 1 May $2011 \quad$ Enhancing the Role of the Boards of Directors of State-Owned Enterprises W. Richard Frederick

N $1 \quad 1$ May $2011 \quad$ Competitive Neutrality and State-Owned Enterprises

Antonio Capobianco, Hans Christiansen 